\title{
Potential of the economic valuation of soil-based ecosystem services to inform sustainable soil management and policy
}

Bartosz Bartkowski ${ }^{\text {Corresp., } 1}$, Stephan Bartke ${ }^{1}$, Katharina Helming ${ }^{2,3}$, Carsten Paul ${ }^{2}$, Anja-Kristina Techen ${ }^{2}$, Bernd Hansjürgens ${ }^{1}$

1 UFZ - Helmholtz Centre for Environmental Research, Leipzig, Germany

2 ZALF - Leibniz Centre for Agricultural Landscape Research, Müncheberg, Germany

3 HNEE - University for Sustainable Development, Eberswalde, Germany

Corresponding Author: Bartosz Bartkowski

Email address: bartosz.bartkowski@ufz.de

The concept of ecosystem services, especially in combination with economic valuation, can illuminate trade-offs involved in soil management, policy and governance, and thus support decision making. In this paper, we investigate and highlight the potential and limitations of the economic valuation of soil-based ecosystem services to inform sustainable soil management and policy. We formulate a definition of soil-based ecosystem services as basis for conducting a review of existing soil valuation studies with a focus on the inclusion of ecosystem services and the choice of valuation methods. We find that so far, the economic valuation of soil-based ecosystem services has covered only a small number of such services and most studies have employed cost-based methods rather than state-of-the-art preference-based valuation methods, even though the latter would better acknowledge the public good character of soil related services. Therefore, the relevance of existing valuation studies for political processes is low. Broadening the spectrum of analyzed ecosystem services as well as using preference-based methods would likely increase the informational quality and policy relevance of valuation results. We point out options for improvement based on recent advances in economic valuation theory and practice. We conclude by investigating the specific roles economic valuation results can play in different phases of the policy-making process, and the specific requirements for its usefulness in this context. 


\title{
1 Potential of the economic valuation of soil-based
}

2 ecosystem services to inform sustainable soil

3 management and policy

4

5

6

7

\author{
Bartosz Bartkowski ${ }^{1}$, Stephan Bartke ${ }^{1}$, Katharina Helming ${ }^{2,3}$, Carsten Paul ${ }^{2}$, Anja-Kristina \\ Techen $^{2}$, Bernd Hansjürgens ${ }^{1}$ \\ ${ }^{1}$ UFZ - Helmholtz Centre for Environmental Research, Leipzig, Germany \\ ${ }^{2} \mathrm{ZALF}$ - Leibniz Centre for Agricultural Landscape Research, Müncheberg, Germany \\ ${ }^{3} \mathrm{HNEE}$ - University for Sustainable Development, Eberswalde, Germany \\ Corresponding author: \\ Bartosz Bartkowski \\ UFZ - Helmholtz Centre for Environmental Research \\ Permoserstraße 15, 04318 Leipzig, Germany \\ Email address: bartosz.bartkowski@ufz.de
}

\section{Abstract}

The concept of ecosystem services, especially in combination with economic valuation, can illuminate trade-offs involved in soil management, policy and governance, and thus support decision making. In this paper, we investigate and highlight the potential and limitations of the economic valuation of soil-based ecosystem services to inform sustainable soil management and policy. We formulate a definition of soil-based ecosystem services as basis for conducting a review of existing soil valuation studies with a focus on the inclusion of ecosystem services and the choice of valuation methods. We find that so far, the economic valuation of soil-based ecosystem services has covered only a small number of such services and most studies have employed cost-based methods rather than state-of-the-art preference-based valuation methods, even though the latter would better acknowledge the public good character of soil related services. Therefore, the relevance of existing valuation studies for political processes is low. Broadening the spectrum of analyzed ecosystem services as well as using preference-based methods would likely increase the informational quality and policy relevance of valuation results. We point out options for improvement based on recent advances in economic valuation theory and practice. We conclude by investigating the specific roles economic valuation results can play in different phases of the policy-making process, and the specific requirements for its usefulness in this context. 


\section{Introduction}

38 In recent years, scientific and political initiatives have been established to emphasize the importance of intact and well-functioning ecosystems for human well-being (Kumar 2010; Pascual et al. 2017; Díaz et al. 2018). However, the attention given to the importance of soils in this context is still limited (Dominati et al. 2010; Baveye et al. 2016). Recently, the older concept of soil functions has been complemented by applications of the ecosystem service perspective to soils (Dominati et al. 2010; Adhikari and Hartemink 2016; Helming et al. 2018; van der Meulen et al. 2018). This helps to illustrate the soils' societal relevance; however, research in this area is still nascent and needs further development. Furthermore, the use and management of soils, particularly in the agricultural context, involves trade-offs between the effects on different ecosystem services as well as biodiversity (Schwilch et al. 2018). There is a need to express these trade-offs in ways that help navigate them and are relevant for policy making. different policy-relevant purposes: informative (e.g. communication of values), decisive (e.g. cost-benefit analysis) and technical (e.g. informing the setting of agri-environmental payment levels) (Laurans et al. 2013). A proper understanding of the potential and limitations of economic valuation is necessary if it is to inform political decision-making processes. In this paper, we conduct a literature review to investigate the current status and the potential of the economic valuation of soil-based ecosystem services to inform sustainable soil management and policy. We seek to contribute to the discussions of whether and to what extent economic perspectives can support the recognition and valuation of soil-based ecosystem services. The economic valuation of ecosystem services, including soil-based ones, is a controversial issue (Baveye et al. 2016); whether valuation studies are conducted in the first place and how they are designed and their results interpreted has consequences for the incorporation of economic values into decision making (Kumar 2010). Our main aim is to shed light on this by evaluating existing attempts to provide economic values of soil-based ecosystem services, and to use insights from economic theory and from the practice of economic valuation in order to suggest ways for improvement. Our paper should be of particular interest for non-economists working in soilrelated environmental sciences. services and treated economic valuation in a less systematic way (e.g. Baveye et al. 2016; Dominati et al. 2010). An exception is Jónsson and Davíðsdóttir’s (2016) review, which focuses on the economic valuation of soils. However, their main interest is in the ranges of monetary values that can be extracted from the literature, while our primary aim is to systematically illuminate how economic valuation is used (from a methodological point of view) and which soil-based ecosystem services have been addressed in economic valuation studies to date. We structure our paper as follows: first, we briefly introduce the methodology used in conducting the literature review (section 2). Second, we develop an operationalized definition of soil-based ecosystem services that will guide our further analysis (section 3). Third, we offer a comprehensive review of existing soil valuation studies with a focus on the ecosystem services 
77 covered as well as the valuation methods applied (section 4). On this basis, we provide a critical

78

79

80

81

82

83

84

85

86

87

88

89

90

91

92

93

94

95

96

97

98

99

100

101

102

103

104

105

106

107

108

109

110

111

112

113

114

115

discussion of the potential and limitations of economic valuation to inform sustainable soil management (section 5). In section 6 we conclude by deriving some more general implications for policy.

\section{Survey methodology}

The core of the present paper is a focused review of existing soil valuation studies. There is a small number of reviews of such studies, including Jónsson and Davíðsdóttir (2016), Robinson et al. (2014), Baveye et al. (2016) and the recent Mapping and Assessment of Ecosystem Services (MAES) report on Soil Ecosystems (van der Meulen et al. 2018), which have different levels of comprehensiveness, different purposes and foci. To provide a comprehensive overview of the relevant literature, we use peer-reviewed studies mentioned in Jónsson and Davíðsdóttir (2016), complemented by additional relevant studies, based on a Web of Science Core Collection topic search for "("economic valu*" OR "monetary valu*") AND soil*" conducted in May 2019. Relevance for the review was assessed on the basis of the abstract. We considered only empirical papers reporting actual valuation studies (and not, e.g., conceptual papers on the topic) that had an explicit link to soils. We derived from the studies especially two types of information: which soil-based ecosystem services are valued (valuation objects), and which methods are used to estimate their economic value. A graphical analysis of the relationships between the ecosystem services addressed in the reviewed studies was conducted in R 3.5.1 (R Core Team 2018), using the igraph package (Csárdi 2019).

The results of the review are reported in section 4.2. Before, we present a conceptual framework of soil-based ecosystem services.

\section{Soil-based ecosystem services}

Agricultural soils fulfil multiple important functions, namely the production of plant biomass, storing and filtering of water, storing and recycling of nutrients, habitat provision, and carbon storage (Schulte et al. 2014; Vogel et al. 2018) with the capacity to provide services to human societies (de Groot et al. 2010). The "direct and indirect contributions of ecosystems to human well-being" that are based on the use or appropriation of these soil functions are called ecosystem services (Kumar 2010, p. xxxiv; see also Boyd and Banzhaf 2007). Soil-based ecosystem services are the outcomes of soil processes that economic valuation focuses on in order to make visible the benefits of soils for human well-being and to inform sustainable soil management and policy. We build on the Common International Classification of Ecosystem Services (CICES V5.1) developed by the European Environment Agency (Haines-Young and Potschin 2018). CICES provides a hierarchical structure that differentiates between abiotic and biotic ecosystem services and groups them into three sections: provisioning services, regulation \& maintenance services, and cultural services. Each CICES section is further subdivided into divisions, groups and classes. In total, there are 84 classes and most assessments of ecosystem 
116 services are conducted at this level, though some studies also shift to higher hierarchical orders

117 where assessment at class level is not feasible.

118 Soil-based ecosystem services are affected by soil management, and agricultural soils are subject

119 to multiple forms of management. Agricultural soil management can be classified into four main

120 categories: spatial cropping patterns, crops and rotations, mechanical pressures, and inputs into

121 the soil (Techen and Helming 2017). The typical soil management practices within each category

122 have different effects on ecosystem services (Schwilch et al. 2018). For instance, spatial

123 cropping patterns influence below-ground as well as above-ground ecosystem services such as

124 pest control through different degrees of habitat heterogeneity (Rusch et al. 2016). Mechanical

125 pressures, such as the weight of machines and tillage, are mainly (but not exclusively) relevant

126 below ground, for instance because they compact the soil and subsequently reduce crop yields

127 and thus provisioning services (Schjønning et al. 2015).

128 Soils are multifunctional and it is not possible to simultaneously maximize the provision of all

129 ecosystem services in one location. In agricultural soil management, trade-offs are unavoidable.

130 They may occur between different services at the same place and time or across spatial and

131 temporal scales, meaning that improvements in one service may imply deterioration of the same

132 or another service at another location or with a certain time lag. This makes their analysis,

133 assessment and valuation challenging. For example, at farm level, narrow crop rotations result in

134 high provisioning services as food and feed production increase. However, at landscape level, the

135 same management results in a low provision of habitats for farmland birds (Gutzler et al. 2015).

136 Considering temporal scales, the application of fertilizer at intervals optimized for plant

137 nutrition, irrespective of soil moisture conditions, results in high provisioning services in the

138 short term. However, if farmers traverse their field with heavy machines during times when soils

139 are too wet, this leads to in soil compaction, which reduces provisioning services in the long term

140 (Frelih-Larsen et al. 2018).

141 The CICES framework is designed to assess services provided by all types of ecosystems rather

142 than tailored to the specifics of agricultural soils. Therefore, some classes are very broad for the

143 context of soils, e.g. class 2.2.4.2 Decomposition and fixing processes and their effect on soil

144 quality, which encompasses the decomposition of biomass, nutrient cycling and nitrogen fixing

145 by leguminous crops. Others are very specific, e.g. classes 3.1.2.3 and 3.1.2.4 that differentiate

146 between aesthetically important and culturally important ecosystems. The partial overlapping of

147 classes and the general complexity of the CICES framework preclude an intuitive understanding,

148 which makes use of the framework in stakeholder communication difficult.

149 For most impact assessments, the number of 84 classes is too high to address. In the context of

150 this paper, in which we address soil-based ecosystem services in agricultural production systems,

151 we focus on the biotic ecosystem services. To derived a list of ecosystem services relevant for

152 our analysis, we applied a two-step process. First, we eliminated services that are not provided

153 by agricultural soils or not affected by agricultural soil management. This resulted in the removal

154 of services provided by animals and such obtained from aquaculture or the gathering of material

155 in the wild. Second, services that are uncommon in conventional agriculture in temperate zones 
156 or only provided within very specific settings were not considered. This led to the removal of

157 multiple services, such as protection against avalanches and landslides, attenuation of smells and

158 noises, or use for education. In this way, we reduced the number of biotic classes from 56 to 22

159 (Table 1). As the importance of spatial and temporal sensitivity both for soil processes (Vogel et

160 al. 2018) and for soil assessment and governance has been emphasized (Juerges et al. 2018), we

161 list for each service the spatial and temporal scales at which the service is mainly provided. Both

162 the selection of services and the determining of main spatial and temporal scales are based on

163 expert assessment by the authors.

164 [TABLE 1 HERE]

165 Having identified soil-based ecosystem services relevant for agricultural production, we now

166 turn to economic valuation in order to shed light on the question, to what degree the above

167 mentioned ecosystem services have been captured through economic valuation so far.

168

\section{Economic valuation of soil-based ecosystem services}

One of the principal ways to assess the societal relevance of soil-based ecosystem services is by means of economic valuation. In this section, we first make some general remarks about the role of economic valuation and the type of information it provides (4.1). We then proceed to a review of soil valuation studies focusing on soil-based ecosystem services and the valuation methods used (4.2). On this basis, we want to highlight some gaps and the as-yet unrealized potential that economic valuation offers in the context of agricultural soils.

\subsection{Key elements of economic valuation in the soil context}

The main rationale for using the economic valuation of environmental goods, including soilbased ecosystem services, is that it allows to compare welfare effects of changes in scarce goods that are not measured in a common metric. The resulting economic values can then be used for different policy-relevant purposes, such as communication of values, cost-benefit analysis and informing the setting of incentive payments (Laurans et al. 2013). For instance, a change in soil management (e.g. tillage) may lead to an increase in one ecosystem service (e.g. carbon storage) at the expense of another (e.g. food production). Economic valuation helps compare the two effects. The management and governance of multifunctional agricultural landscapes requires frequent decisions in trade-off situations. By facilitating comparison between different dimensions of a problem via expressing diverse impacts in one value unit (i.e. monetary terms), economic valuation is expected to help navigate such trade-offs. For instance, it may show that the production loss associated with applying minimum tillage is outweighed by the increase in soil water capacity (and thus water flow regulation and flood protection) (Pereira et al. 2018). Or it helps assess the trade-off between agricultural production on drained organic soils and the carbon storage in those soils when they are rewetted (see Albert et al. 2017).

193 Economic valuation has received a fair share of criticism (Hausman 2012; Baveye et al. 2016) 194 and its results should be treated with caution and as one among many contributions to political

195 decision making. Still, its role in many political processes is strong; so is the demand for 
196 monetary values to inform e.g. the design of agri-environmental payment schemes or the

197

198

199

200

201

202

203

204

205

206

207

208

209

210

211

212

213

214

215

216

217

218

219

220

221

222

223

224

225

226

227

228

229

230

231

232

233

assessment of infrastructure projects with environmental consequences (Förster et al. 2019).

Therefore, it is essential to identify valuation results of (relatively) high informational value and be aware of their limitations. This is particularly important in the context of soils and soil-based ecosystem services, where economic valuation is becoming increasingly widespread (see section 4.2). Here, we do not aim for a comprehensive introduction (for this, see Pascual et al. (2010); in the context of soils, Baveye et al. (2016)). Rather, after briefly introducing the overarching concept of Total Economic Value (TEV) (Krutilla 1967; Pascual et al. 2010), we highlight two fundamental aspects of economic valuation - the focus on incremental changes and the central role of preferences - that are informative when making and analyzing choices with respect to valuation methods, an issue to which we will return in section 4.2.

The most basic framework used in the economic valuation of environmental goods is Total Economic Value. Its main feature is the distinction between use values, associated with actually using the environmental good directly or indirectly, and non-use values, which do not require the environmental good being used by the valuer, i.e. the person ascribing value to the environmental good, herself. Furthermore, there are the additional categories of option value and insurance value, which have no agreed-upon "position" within the framework (Pascual et al. 2010). Especially the latter - insurance value - has become the focus of much conceptual research only recently, including in the context of soil valuation (Pascual et al. 2015). Figure 1 shows an extension of the original TEV with insurance value, based on Pascual et al. (2015) and Bartkowski (2017). Here, the additional category of uncertain-world values encompasses values that arise when there is uncertainty over the future demand and supply of ecosystem services, namely option and insurance value, which are mainly attributable to (soil) biodiversity (Bartkowski 2017; Pascual et al. 2015). Meanwhile, the conventional TEV categories can be found within certain-world values, i.e. they are untouched by and independent of considerations of uncertainty. Agricultural soils provide a range of direct and indirect use values; most soilbased provisioning services can be viewed as generating direct use values, while regulating services are usually associated with indirect use values. Moreover, any soil-based ecosystem service can also have altruistic or bequest value if it is viewed as benefiting others, while existence value is mainly attributable to objects, including soils as such. ${ }^{1}$ Note that non-use values can be estimated only by means of stated preference methods; also, option value and insurance value are most easily captured by means of this method type (Bartkowski 2017). This is the case because non-use values are by definition not expressed in market behaviour and cannot be traced back to market choices. Thus, one needs to apply hypothetical, survey-based valuation methods to obtain information on non-use values.

[FIGURE 1 HERE]

In addition to the TEV, there are two major characteristics of economic valuation that have particular relevance for the choice among and relative merit of the available valuation methods.

${ }^{1}$ In fact, CICES includes existence value and bequest value as individual ecosystem services, attributable to "characteristics or features of living systems" (see Table 1).

Peer) reviewing PDF | (2019:10:42110:2:0:NEW 4 Feb 2020) 
234 First, economic valuation deals with incremental changes in the quality or quantity of a good's 235 supply. It always implies a trade-off, a potential exchange of one scarce good against another. 236 This, of course, presupposes substitutability - non-substitutable, essential goods cannot be 237 sensibly expressed in terms of economic value (other than the value being infinite, see Toman 238 1998; Bockstael et al. 2000). The centrality of the substitutability assumption also leads to the 239 usual approach of estimating the economic value of incremental (best: marginal) changes in the quantity or quality of the good in question - the reasoning being that small changes in almost any good are substitutable, while larger changes may not be. Thus, economic valuation studies are usually based on the comparison of two marginally different states of the world (one usually being the status quo), for instance analyzing the preferences towards changes in soil-based ecosystem services resulting from a given change in agricultural management practices. The second important and only seemingly trivial characteristic of economic valuation is that its goal is to provide a measure of preferences, i.e. subjective evaluations made by people, reflecting the relative scarcity of different goods and the trade-offs between them. ${ }^{2}$ This implies, first, that economic valuation has an inherently anthropocentric focus - though non-anthropocentric considerations may and often do enter "through the back door" when they underlie the preferences observed among and expressed by valuing actors (Spash 2006; Martín-López et al. 2007). Second, and more importantly in the context of the present paper, a proper economic valuation study should be based on some way of observing or eliciting preferences. While other kinds of proxies are admissible in light of high resource demands and low precision requirements, economic valuation sensu stricto is an expression of preferences. These can be measured directly, by means of questionnaires eliciting preferences for hypothetical scenarios of change (stated preference methods), or indirectly by means of statistical analyses of observed behaviour in markets that can be linked to environmental goods (revealed preference methods). In the broad sense, the commonly used cost-based valuation methods, which generally approximate the economic value of an ecosystem or an ecosystem service by looking at the costs of its replacement, restoration, preservation etc., are seen as a class of economic valuation methods. However, they do not offer any insights into preferences - they can only tell us something about technical possibilities and the costs thereof. For instance, if the replacement cost approach is used to estimate the economic value of the flood protection service of a riparian landscape, one may use the cost of installing flood walls in downstream towns as a proxy. However, this may be both an underestimate (if people were actually willing to pay much more to preserve the flood protection service) and an overestimate (if they preferred the increased risk of flood to paying for the flood walls). Without additional information on preferences, we cannot know how accurate the proxy-based value is.

One could argue that the appropriateness of applying cost-based methods depends on whether the ecosystem service in question is in its essence a private good, such as e.g. food production, or

${ }^{2}$ There is a long-standing debate whether observed preferences can be translated into utility, i.e. whether there is an intricate link between the two (Samuelson 1938; Sen 1973). This debate has repercussions for the theory of economic valuation (Aldred 1994); here, we follow Aldred (1994) in restricting the domain of economic valuation to preferences, without linking it to the more problematic concept of utility. 
271 a public good, such as e.g. nutrient cycling (see Bartkowski et al. 2018). The reason is that the

272 costs that are used as proxy would indeed be borne by the person managing the land/soil and thus

273 "responsible" for changes in the ecosystem service. Therefore, using a cost-based proxy

274 essentially reflects the soil manager's calculus. Even though it still does not reflect her

275 preferences, the two implicitly compared options (management for or the loss of the ecosystem

276 service) are indeed the options faced by the same person. ${ }^{3}$ On the other hand, for public

277 ecosystem services, the use of cost-based proxies is more problematic, as here the implicit trade-

278 off does not reflect the calculus of an individual agent, but rather of two different (groups of)

279

280 agents. In such a situation, information on actual preferences is much more essential for guiding decisions. Since most ecosystem services, including soil-based ones, are public goods, this still

281 implies that the application of cost-based valuation methods is problematic.

282 Of course, applying preference-based valuation methods does not per se lead to valid results. It is advisable to follow guidelines for the application of such methods, as outlined e.g. in Johnston et al. (2017) for stated preference methods and in Riera et al. (2012) for both revealed and stated preference methods. Even then, given the complexity of ecosystems and the many factors influencing human decision making, results of economic valuation studies should be interpreted primarily as giving orientation about orders of magnitude and value ranges (see Förster et al. 2019), rather than offering precise values (we will come back to this in section 5). Still, following guidelines such as those referred to above and making use of advances in study design and analysis, precision and relevance for political purposes can be increased.

\subsection{Soil valuation studies: valuation objects and methods}

\subsubsection{Overview}

294

295

Table 2 provides a list of the studies included in the review, together with the year of study

296 (where applicable and identifiable), study area and a categorization into studies estimating total versus marginal values of soil-related ecosystem services.

297 [TABLE 2 HERE]

298 Among the 43 studies included here, 13 were conducted in North America (US or Canada), 12 in 299 Europe and nine in Asia.

300

\subsubsection{Ecosystem services studied}

302 The coverage of soil-based ecosystem services in soil valuation studies is quite uneven. Most of

303 them focus on a handful of ecosystem services (particularly Climate regulation and

304 Decomposition and fixing) whose value can be estimated relatively easily. Also, there exist

\footnotetext{
${ }^{3}$ This reasoning abstracts from the problem of myopic agents, who do not properly consider the consequences of their actions on themselves if these consequences are to be expected in the future - in other words, they discount these consequences heavily. This issue is particularly relevant in the case of agricultural soils, where tenancy has been shown to foster short-term oriented management by the tenant (Soule et al. 2000; but see Leonhardt et al. 2019). Here, however, it may be argued that the case is similar to public goods - the trade-off implicit in the use of a cost-based proxy does not reflect the calculus of a single agent, but rather of two agents (tenant and owner).
} 
306 of the CICES ecosystem service Erosion control. But soil erosion may also be interpreted as

307 negatively affecting a bundle of soil-based ecosystem services - most of the papers in this

308 context do not, however, disentangle the different ecosystem services and benefits affected by

309 the loss of topsoil. ${ }^{4}$ Conversely, there are hardly any studies investigating cultural ecosystem

310 services provided by soils. In what follows, we briefly discuss the most widely valued soil-based

311 ecosystem services. For an overview of the estimate ranges across different studies, see Jónsson

312 and Davíðsdóttir (2016). The combinations of particular valuation methods and specific soil-

313 based ecosystem services found in the literature are depicted in Table 3 and will be critically

314 discussed further below.

315 [TABLE 3 HERE]

316 The most comprehensive economic valuation studies of soil-based ecosystem services were

317 conducted by Dominati and colleagues in New Zealand (Dominati et al. 2014a,b). Using

318 predominantly cost-based valuation methods, they analyzed a number of soil-based ecosystem

319 services in different landscapes, including: (agricultural) biomass production (CICES: Food

320 production, Materials, Energy), physical support of animals and infrastructure, flood mitigation

321 (Hydrological cycle), nutrient cycling (Decomposition and fixing), climate regulation, and pest

322 control. A network graph depicting the co-occurrences of the different ecosystem services across

323 studies can be found in Figure 2. Dominati et al. (2014b) found that nutrient cycling and flood

324 mitigation are responsible for the largest share of soils' total economic value. In a pastoral

325 agricultural landscape in New Zealand, Dominati et al. (2014a) found that the value of soil-based

326 regulating services is about 2.5 times as high as that of soil-based provisioning services. In this

327 case, the services with the highest value were what the authors called filtering of nutrients and

328 contaminants (Bio-remediation/Filtration/Sequestration), followed by the provision of food

329 (Food production) and flood mitigation (Hydrological cycle). A similarly comprehensive

330 approach can be found in Porter et al. (2009) and Sandhu et al. (2008), who included a number of

331 soil-based ecosystem services (nitrogen regulation, soil formation, soil carbon/carbon regulation,

332 hydrological flow) in their comparisons of different types of agriculture in Denmark and New

333 Zealand, respectively.

334 [FIGURE 2 HERE]

335 Other studies had a much narrower focus, usually on single soil-based ecosystem services. We

336 ignore here those soil-based provisioning ecosystem services, such as food, fibre and raw

337 materials, whose economic value can be derived or at least approximated by means of market

338 prices (see Jónsson and Davíðsdóttir 2016; Robinson et al. 2014).

339

340 4.2.2.1 Water-related ecosystem services

341 The contribution of soils to water quality and fresh water provision (Regulation of freshwater

342 chemistry) can be approximated by means of the replacement cost method - how much does it

\footnotetext{
${ }^{4}$ It should be noted that this is to some extent true for many soil-based ecosystem services, e.g. carbon storage, which has an influence on other ecosystem services as well. In fact, interdependencies between ecosystem services are the norm rather than an exception (Cord et al. 2017). However, soil erosion is "special" as it matters only because of the other ecosystem services it affects.
} 
343 cost to clean water for drinking (i.e. if cleaning is not "done" by soils)? This approach has been

344 applied by Tegtmeier and Duffy (2004). Another possible approach, chosen for instance by

345 Dominati et al. (2014a,b), is to look at nutrient retention by soils more directly, and value it by

346 means of methods such as provision costs and avoidance costs (in the case of nutrient leaching).

347 A soil-based ecosystem service that is frequently studied in valuation studies is the hydrological

348 cycle, including flood protection (mostly cost-based methods), see e.g. Hansen and Hellerstein

349 (2007) or Tegtmeier and Duffy (2004). They use the costs of alternative measures of flood

350 protection to approximate the economic value of soils' capacity to store water. In a more direct

351 approach, Kay et al. (2019) used water prices for this soil-based ecosystem service, interpreting

352 it as groundwater recharge.

353

354

\subsubsection{Climate regulation}

355

The economic value of carbon sequestration in soils (Climate regulation) can be estimated

356 seemingly easily on the basis of the various estimates of social cost of carbon (SCC) available in the climate economics literature (van den Bergh and Botzen 2015) or using carbon prices in emissions trading schemes. The latter approach, however, is problematic, as these prices usually do not reflect the marginal damage costs of carbon in terms of its contribution to climate change, but rather are a result of political decisions such as the cap level, the method of the first distribution of emission certificates (e.g. grandfathering or auctioning), leakage effects due to the coverage of only some sectors of the economy etc. (Hintermann et al. 2016). SCC estimates are usually generated by means of integrated assessment models (IAM). The estimates are very sensitive to a number of model parameters (Ackerman et al. 2009), especially the so-called damage function, which links changes in global temperature to losses in terms of capital, production, human lives etc., and the social rate of discount, which allows the comparison of effects occurring at different points in time, and which enticed a large and controversial literature of its own (Arrow et al. 2014). As a result, SCC estimates vary in the range of orders of magnitude (van den Bergh and Botzen 2015) and it is by no means clear which estimate to use when valuing, e.g., carbon storage by soils. A noteworthy study using this approach is Hungate et al. (2017), who used SCC estimates to value the contribution of soil biodiversity to carbon storage. An alternative to the use of SCC estimates is the approach by Rodríguez-Entrena et al. (2012), who conducted a choice experiment to evaluate the demand for carbon sequestration in olive grove soils in Andalusia (Spain) and came up with a willingness to pay by the general public of 17 EUR per ton $\mathrm{CO}_{2}$ per person - as compared to a range of 5 to 106 USD in studies using the most common IAMs (van den Bergh and Botzen 2015). A similar approach, though with a focus on ancillary effects of soil carbon management, was used by Glenk and Colombo (2011) in Scotland. Another study worth noting in this context is Noe et al. (2016), who used a Monte Carlo analysis of SCC estimates to identify the value of carbon storage in Minnesota prairies; they found an average value of 73 USD per ha per year. In another study, Jerath et al. (2016) estimated the economic value of carbon storage in the Everglades (US), showing that carbon storage in soils amounts to between 77 and 90 per cent of the overall value across study 
383 sites. Lu et al. (2013) used a rather unconventional approach for valuing climate regulation by 384 soil carbon storage, namely approximating it by the costs of planting trees that would bind an 385 equivalent amount of carbon.

386

\subsubsection{Cultural ecosystem services}

388 The economic valuation of cultural ecosystem services is a challenge even beyond the context of

389

390

391

392

393

394

395

396

397

398

399

400

401

402

403

404

405

406

407

408

409

410

411

412

413

414

415

416

417

418

419

420

421

422 soils (Baveye et al. 2016; Chan et al. 2012). Valuation studies of soil-based cultural ecosystem services are scarce; the only one cited by Jónsson and Davíðsdóttir (2016) in their comprehensive literature review is the conference paper by Eastwood et al. (2000), who estimated the economic cost of soil erosion in terms of recreational loss in New Zealand. A similar approach can be found in Tegtmeier and Duffy (2004), who looked at the damage costs of sedimentation in rivers (caused by agricultural soil loss) in terms of foregone river-based recreation. In their study of the economic value of erosion control, Almansa et al. (2012) mention a few "benefits" of erosion control that can be interpreted as cultural ecosystem services (e.g. "increase in aesthetic and recreational use", "rural tourism"). However, as they elicit willingness to pay (WTP) for an erosion control programme as a whole, they cannot distinguish between the relative contributions of the various benefits to the overall WTP.

\subsubsection{Other ecosystem services}

We did not find valuation studies looking at the soil-based ecosystem services Maintaining habitats, Disease control and microclimatic regulation (Regulation of temperature/humidity/ventilation/transpiration) or most cultural ecosystem services - despite their importance for the overall picture of soils' contributions to human well-being (Helming et al. 2018; van der Meulen et al. 2018). Of those soil-based ecosystem services that have actually been recognized in valuation studies, many have been included only infrequently. For instance, Chemical regulation of freshwaters - a crucial ecosystem service related to the nexus connecting agriculture with aquatic ecosystems - can only be found in five studies. Pest control, highly important given the agronomic relevance of soil-living pests (e.g. Kulmatiski et al. 2014), occurs in only three soil valuation studies. Soil-based cultural ecosystem services are almost completely missing, while the economic value of the non-CICES ecosystem service/soil function Physical environment (for human structures, housing, livestock etc.) has only been studied by Dominati et al. $(2014 a, b)$.

\subsubsection{Valuation methods}

Table 3 above summarizes the application of valuation methods in studies estimating the economic values of different soil-based ecosystem services. Most soil valuation studies use costbased methods or market price proxies to estimate the economic value of soil ecosystem services. Both approaches have limits - as mentioned in section 3.1, cost-based methods are easy to use but inconsistent with economic theory. Furthermore, the impact of the technical solutions whose costs are used as proxy of ecosystem service value on other ecosystem services are 
423 usually not taken into account. Market price proxies (e.g. the price of topsoil, Robinson et al. 424 (2014)) are also problematic. In most cases, the market good (e.g. topsoil) is not equivalent to

425

426

427

428

429

430

431

432

433

434

435

436

437

438

439

440

441

442

443

444

445

446

447

448

449

450

451

452

453

454

455

456

457

458

459

460

461

462 any soil-based ecosystem service, so its price is only a very rough proxy. Moreover, market prices are usually distorted due to imperfect markets (caused by taxes/subsidies, market power etc.). Thus, such approaches can be helpful as a first estimate, but their informational quality is limited in most cases. However, as Table 3 shows, they are quite common in the context of valuing soil-based ecosystem services.

Theoretically, land prices should reflect, among other factors such as proximity to public infrastructure, the value of soil-based ecosystem services, at least those that directly benefit landowners. Thus, "one would think that it would be feasible to disaggregate land prices into the prices of the various below- and above ground components of land, and eventually to estimate the monetary value of soils" (Baveye et al. 2016, p. 28). As it turns out, however, the actual disentanglement of the relative contributions of the relevant factors to the price of land, is anything but straightforward and simple. Hedonic pricing is the standard approach here, which consists in a statistical analysis of various factors influencing land or real estate prices. In a rare instance of such an analysis of land prices, Samarasinghe and Greenhalgh (2013) used a hedonic pricing approach to determine the influence of inherent characteristics of soils on farmland prices in New Zealand. However, they did not explicitly value soil-based ecosystem services.

Furthermore, such an approach would only allow for the estimation of private-good type soilbased ecosystem services. Public benefits are not likely to be reflected in land prices. Even private benefits such as the yield potential of soils are not necessarily related to land prices (Daedlow et al. 2018).

There are only a few instances of stated preference methods being applied in the soil valuation context. For example, the already mentioned study by Almansa et al. (2012) analyzes the social benefits of erosion control by comparing restoration costs and contingent valuation - they find that the latter results in WTP estimates around twice as high as the former. Rodríguez-Entrena et al. (2012) also focus on erosion and erosion control in olive groves while using a choice experiment. However, they find negligible WTP for erosion control. Colombo et al. (2006) use a choice experiment to estimate the WTP for a reduction of off-site consequences of soil erosion.

A choice experiment was also used in the already mentioned study by Glenk and Colombo (2011). Cerda et al. (2018) include in their choice experiment an attribute soil quality, which cannot be easily linked to any specific soil-based ecosystem service.

Overall, Table 3 highlights two common features: (i) a strong bias in favour of the easiest-to-use, fairly transparent and easily reproducible, but also most imprecise and theoretically problematic cost-based methods; and (ii) a rather strong focus on a small number of particularly easy-toquantify soil-based ecosystem services that can be easily valued, especially Decomposition and fixing (usually valued by means of the proxy of fertilizer costs) and Climate regulation via carbon storage (valued using SCC estimates or market prices). An exception are the many soil erosion control studies, as soil erosion affects many different soil-based ecosystem services across spatial and temporal scales. However, except for Pimentel et al. (1995), none of them 
463 differentiates between the various elements of the ecosystem service bundle affected by soil

464

465

466

467

468

469

470

471

472

473

474

475

476

477

478

479

480

481

482

483

484

485

486

487

488

489

490

491

492

493

494

495

496

497

498

499

500

501

erosion. Even in the few studies that considered more than one soil-based ecosystem service (e.g. Pimentel et al. 1995; Dominati et al. 2014a,b; Sandhu et al. 2008; Porter et al. 2009), only costbased valuation methods were used and for each ecosystem service, the economic value was estimated separately. Meanwhile, more advanced valuation methods such as hedonic pricing or choice experiments allow for estimating the WTP for multiple ecosystem services simultaneously, reflecting trade-offs between them. Furthermore, we do not find any apparent changes over time with respect to both ecosystem service selection and choice of valuation methods.

\section{Economic valuation for sustainable soil management and policy}

The economic valuation of soil-based ecosystem services has the potential to ensure public awareness on societal importance of soils, including agricultural soils. It can do so by emphasizing that the contributions of soils to human well-being - via food production, flood protection and other effects - are valuable despite not having a market price. Furthermore, it can show how valuable contributions of soils are affected by soil management - and thus inform agricultural, environmental and other policies relevant for soils (e.g. Glæsner et al. 2014; Turpin et al. 2017; Vrebos et al. 2017). Moreover, the economic valuation of soil-based ecosystem services may offer pathways for developing policy instruments, such as agri-environmental payments for management practices that promote soil-based ecosystem services. However, as shown in the review in the previous section, the economic valuation of soil-based ecosystem services has not yet lived up to this potential for multiple reasons. In the following, we will discuss where we see untapped potentials, but also point to limitations of economic valuation in the context of soils.

Most obviously, the widespread use of cost-based valuation methods should be viewed critically for reasons mentioned in section 3.1. They can be helpful in providing first rough estimates - but economics has to offer much more sophisticated valuation methods that are more informationally rich. While stated preference methods have been criticized because of validity and reliability problems (e.g. Hausman 2012; Rakotonarivo et al. 2016), proper design following standard guidelines helps avoid many of the problems involved (Riera et al. 2012; Johnston et al. 2017; Bishop and Boyle 2019).

It is important to emphasize that for economic values to be meaningful, their estimation should be based on environmental/land-use changes - while many existing soil valuation studies rather focus on the economic value of states, without explicit reference to (scenarios of) change (see Table 2). Especially in policy contexts, however, information about the economic value of changes in the provision of soil-based ecosystem services is crucial (see Förster et al. 2019). For instance, if economic values are to inform the setting of payment levels for result-based agrienvironmental schemes (Burton and Schwarz 2013), it is necessary that they can be expressed in terms of the change that the scheme is meant to incentivize. In any case, informing the setting of 
502 incentives requires high-quality valuation studies conducted specifically for this purpose; a direct

503 transfer of economic values from one study to another context would be problematic.

504 There are also clear challenges involved in the economic valuation of soil-based ecosystem

505 services generally, beyond the use of particular methods and focus on particular ecosystem

506 services. For instance, the relevant temporal and spatial scales are a challenge. As indicated in

507 Table 1, different soil-based ecosystem services are relevant at different temporal scales - thus,

508 the same environmental and management change will be "felt" in terms of ecosystem service

509 provision at different points in time. This implies that different relevant stakeholders, who weigh

510 soil-based ecosystem services differently, will have different preferences with respect to a given

511 soil management or land-use change. Here, economic valuation has both potential and an

512 important limitation. On the one hand, it requires the identification of all relevant stakeholders

513 (Pascual et al. 2010), which is helpful here. On the other hand, economic valuation is based on

514 the Kaldor-Hicks criterion, i.e. it does not distinguish between winners and losers, but focuses on

515 aggregate preferences. Therefore, to distinguish heterogeneous preferences resulting from the

516 different time scales involved in soil-based ecosystem services, additional, complementary

517 methods are necessary. Another possibility would be to apply economic valuation, but to

518 distinguish between the WTP of different groups (Cavender-Bares et al. 2015).

519 With respect to the spatial dimension, an economic valuation study should be based on a proper

520 understanding of the particular systemic, emergent effects of land-use changes from which

521 economic values are to be derived. Here, multiple challenges arise. First, the ex-ante assessment

522 (e.g. by means of modelling, see Vogel et al. 2018) of the specific effects of a given land-use

523 change on soil functions and soil-based ecosystem services involves many uncertainties and is

524 very case-specific. Recently, novel design approaches to deal with ecosystem service uncertainty

525 in stated preference studies have been developed (Czajkowski et al. 2016; Faccioli et al. 2019),

526 which explicitly include uncertainty in the scenarios to be evaluated by respondents (e.g. as

527 attributes in a choice experiment). Second, there is a need to scale up the results in order to

528 translate them to societally relevant spatial levels, usually landscapes. Here, combining effects of

529 land-use or soil-management changes on soil functions with other, non-soil factors adds to the

530 complexity. For instance, it is non-trivial to find adequate indicators linking spatial levels.

531 However, it is crucial to understand the trade-offs involved at both (stylized) levels. The spatial

532 dimension is also crucial in a more general sense, as "multiple authors have demonstrated or

533 argued that the relevance of spatial patterns for policy evaluation can outweigh comparable

534 effects of statistical or methodological issues that are often given greater attention in the

535 literature [on economic valuation]" (Glenk et al. 2019, p. 2). For example, the geographic

536 location of different groups of stakeholders/beneficiaries vis-à-vis the spatial extent of different

537 soil-based ecosystem services is relevant and adds to the complexity mentioned above with

538 respect to different time scales (Budziński et al. 2018). Also, soil management is spatially

539 specific, so it may trigger different changes in the provision of soil-based ecosystem services

540 across the landscape; their consequences for human well-being and the associated economic

541 values depend on spatial interdependencies and patterns as well as neighbourhood effects. So far, 
542 even though the spatial nature of many soil-related ecosystem services is rather obvious, little 543 attention has been given to its relevance for economic valuation. Approaches and methods that 544 help to accommodate these considerations are available. They need to be taken up in the context 545 of soil-based ecosystem service valuation.

546 Estimating the relative contribution of soils to the provision of most ecosystem services (and, 547 thus, to their economic value) is a problem that is particularly difficult to resolve. For some 548 ecosystem services, isolation of the contribution of soils may be possible, for example climate 549 regulation via carbon storage. Yet, for many others, the interactions behind the provision of 550 ecosystem services are way too complex - in terms of system understanding, but also when it 551 comes to definitions distinguishing between soil and other (related) factors. Rather, it is the case 552 that soil functions contribute to multiple ecosystem services, but they are usually not identical 553 other factors play an important role as well. For instance, what is the soil's contribution to the 554 economic value of food production as compared to above-ground vegetation? What about soil's capacity to store water as contribution to flood protection? The question is, however, what the point of such "distilling" the relative contribution of soils may be. For policy purposes, it seems rather irrelevant - here, the relevant leverage points are above all management practices, which are not limited to affecting soils only. A related issue is the widely discussed (Boyd and Banzhaf 2007) close interaction between natural and human contributions to the provision of ecosystem services. In the context of agriculture, the provision of soil-based ecosystem services strongly depends on the interaction between biogeochemical processes and human management. For example, the provision of food from an agricultural field relies on human management such as the sowing of seeds and on natural factors such as rainfall. Since it is the (soil-based) ecosystem services which are valuable for human well-being, it is relevant how they (and their economic value) respond to changes in management, while the relative contribution of soils to these responses is, if anything, of purely academic interest. Furthermore, for policy purposes, it is essential to identify and take into account changes in the economic value of all affected ecosystem services when the consequences of a change in management, land use or other boundary conditions are investigated.

570 Overall, to be informative and useful for various policy purposes, the economic valuation of soilbased ecosystem services should make use of state-of-the-art approaches and methods. Particularly, we emphasize the importance of preference-based methods that allow for disentangling various attributes (ecosystem services) and their relative values (choice experiments, hedonic pricing). Moreover, these methods should be applied in line with established guidelines (Riera et al. 2012; Johnston et al. 2017; Bishop and Boyle 2019). Another important point of particular relevance to the valuation of soils is taking into account spatial heterogeneity by means of appropriate methods and approaches (for an overview, see Glenk et al. 2019). Last but not least, here and elsewhere, the limitations of economic valuation should be acknowledged (see Baveye et al. 2016; Pascual et al. 2010) and the application of hybrid or nonmonetary methods should be considered where these limitations are particularly severe, e.g. in 
581 the case of cultural soil-based ecosystem services (see Christie et al. 2012; Hattam et al. 2015;

582 Lienhoop et al. 2015).

583

584

585

\section{Relevance of the economic valuation of soil-based ecosystem services for policy making}

586

587

588

589

590

591

592

593

594

595

596

597

598

599

600

601

602

In this paper, we provided a comprehensive review of existing soil valuation studies with a focus on the ecosystem services addressed as well as the valuation methods applied. We found that preference information on soil-based ecosystem services (as provided by valuation studies) is scarce and that a small number of services is overrepresented (particularly those related to soil carbon storage and nutrient cycling). While there exist valuation approaches that would help improve the quality of information provided by soil valuation studies, they have not yet been applied in this context. Most existing studies rely heavily on rather imprecise and theoretically problematic cost-based methods.

For economic valuation to inform decisions and guide them, the quality of soil valuation studies needs to improve. Currently, the required level of quality is not given and the informational value of existing valuation results is low. In particular for services relating to aesthetic, spiritual or cultural values, reliable valuation methods are missing. Future research will have to elucidate in how far economic valuation is suitable to represent those services and whether other, hybrid or non-monetary methods are more appropriate for this purpose. More generally, economic valuation needs to be complemented with other perspectives better reflecting values related to cultural ecosystem services, while at the same time accounting for diverse issues such as equality, legitimacy or human health (see e.g. Brevik et al. 2019).

603 For many other services, however, the application of established, state-of-the-art methods could make economic valuation a valuable tool to support political decision making - especially so if

605 existing approaches that allow to account for the heterogeneity and multifunctionality of soils are drawn upon. In what follows, we want to shed some light on the potential role of economic valuation in policy-making processes while applying the concept of a policy cycle. As stated in the introduction, economic values can be policy relevant in different ways, being informative, decisive, and/or technical (Laurans et al. 2013). Thus, the economic valuation of soil-based ecosystem services has implications at various levels and purposes for land-use and soil-related policies. Following Wegrich and Jann (2007), four phases of a typical policy-making process can be distinguished: (1) agenda setting, (2) policy formulation and decision making, (3)

613 legitimation and implementation, and (4) evaluation and termination. At each stage, economic valuation can potentially contribute, though given the currently poor state of the empirical

615 literature reviewed above, its potential is still largely untapped. In the following, we point to the 616 requirements future soil valuation studies should fulfil to become relevant for the different stages 617 of the policy cycle (based on the discussion in the previous section).

618 In the context of the agenda setting phase of the policy cycle, economic valuation has been used 619 to emphasize market failures and the need for state intervention (Bromley 1996; Hubacek and 620 van den Bergh 2006; Bartkowski et al. 2018) by pointing out the non-market value of soil-based 
621 ecosystem services. As Braat (2013) emphasizes, valuation processes can be interpreted "as a 622 form of regulatory adaptation via positive and negative feedback in an economic system. In this 623 view, the valuation of changes in biodiversity, natural capital, and ecosystem services becomes a

624 logical and necessary element of a sustainable development policy cycle" (p. 101). In the context 625 of agenda setting, precision and state-of-the-art methodologies do not play a large role; however, 626 a comprehensive set of values for different ecosystem services is necessary for a broad picture of 627 soils' societal importance, which may need to go beyond economic values.

628 When it comes to policy formulation, economic valuation can contribute important information 629 needed to set the policy objective at an effective aim - i.e. to clarify which end shall be achieved 630 by an intervention. On the strategic level, valuation of soil-based ecosystem services can help 631 decision makers on the local to global level design instruments fostering sustainable soil 632 management. The multifunctionality of soils is the major challenge for target setting 633 (effectiveness) before determining the means to get there (efficiency). In the context of policy 634 formulation, precise estimates based on state-of-the-art methods are crucial. Also, they should be 635 available for the full suite of soil-based ecosystem services. Uncertainties regarding the 636 underlying biophysical phenomena and the valuation itself should be clearly communicated (e.g., 637 it is not sensible here to work with single values, but rather with value ranges or indications of 638 the level of confidence on which a given value estimation is based, following standards 639 established in the context of the IPCC, see Helgeson et al. 2018).

640 With respect to the legitimation phase of the policy cycle, it should be emphasized once more 641 that low-quality estimates of the economic value of soil-based ecosystem services can have 642 detrimental effects in terms of legitimacy of the policies they inform (see Droste and Meya 643 2017). This strengthens the call of this paper for better, state-of-the-art and comprehensive 644 valuation studies in the soil context.

645 Economic valuation can be a useful instrument to assess if policies are efficient and achieve the 646 desired effects. However, it has also been pointed out that policy makers often follow short-term, 647 cost-benefit paradigms to avoid short-term costs for voters and stakeholders (e.g. Göpel 2016). 648 Transparent assessments can help compare and consider short- and long-term impacts. Yet, the 649 application of economic valuation in policy making is still not common - in particular, more 650 complex modelling and monetization methods are rarely applied (Turnpenny et al. 2015) - and is 651 challenged by temporal and spatial sensitivity and dispersion of decisions and impacts. A typical 652 problem faced by governance of natural resources is the spatial mismatch of ecological

653 functional units and geographical policy-relevant units related to jurisdictions or property owners 654 (Cash et al. 2006; Leventon et al. 2019). As pointed out by Juerges et al. (2018), soil policies in 655 administrative boundaries have to consider ecological boundaries, too. Given the complexity of 656 the soil system (Vogel et al. 2018) and the soil challenges (Nathanail et al. 2018), an assessment 657 at multiple spatial scales is required (Artmann 2015). To be fruitful, economic valuation is 658 needed at the (spatial) scale referring to the policy objective (agenda setting) with the respective 659 time scales and inherent value system (Campbell et al. 2001). In this context, it is essential to use 660 economic valuation in combination with other sources of information in a holistic, systemic 
661 manner (Vogel et al. 2018): for instance, ex-ante evaluation of changes in soil policy and

662 management can be assessed by the combination of systemic process modelling with economic

663 values to find out whether the changes have had welfare-increasing effects.

664 Overall, our review and the following analysis of the potential role of the economic valuation of 665 soil-based ecosystem services in land-use policy suggest that while economic valuation can be 666 useful and informative, the current status of the literature in this area is unsatisfactory and needs 667 significant improvement. We showed that state-of-the-art preference-based valuation methods 668 and recent developments that take into account spatial effects and uncertainty could improve the 669 quality of value estimates for soil-based ecosystem services. Further, we highlighted which role 670 economic valuation can play at various stages of soil policy making. First, however, there is an 671 urgent need for improvement in methodological rigour in this area.

672

673

\section{Acknowledgements}

674

We would like to thank Victoria Dietze for assistance with literature search, Anne Wessner for a

675 language check, as well as Julian Massenberg and the two reviewers for valuable comments. The

676

677

678 usual disclaimer applies.

\section{References}

679

680

681

682

683

684

685

686

687

Ackerman, F., DeCanio, S.J., Howarth, R.B., Sheeran, K., 2009. Limitations of integrated assessment models of climate change. Clim. Change 95, 297-315. https://doi.org/10.1007/s10584-009-9570-x

Adhikari, K., Hartemink, A.E., 2016. Linking soils to ecosystem services - A global review. Geoderma 262, 101-111. https://doi.org/10.1016/j.geoderma.2015.08.009

Alam, M., Olivier, A., Paquette, A., Dupras, J., Revéret, J.-P., Messier, C., 2014. A general framework for the quantification and valuation of ecosystem services of tree-based intercropping systems. Agrofor. Syst. 88, 679-691. https://doi.org/10.1007/s10457-0149681-X

Albert, C., Schröter-Schlaack, C., Hansjürgens, B., Dehnhardt, A., Döring, R., Job, H., Köppel, J., Krätzig, S., Matzdorf, B., Reutter, M., Schaltegger, S., Scholz, M., SiegmundSchultze, M., Wiggering, H., Woltering, M., von Haaren, C., 2017. An economic perspective on land use decisions in agricultural landscapes: Insights from the TEEB Germany Study. Ecosyst. Serv. 25, 69-78. https://doi.org/10.1016/j.ecoser.2017.03.020

Aldred, J., 1994. Existence value, welfare and altruism. Environ. Values 3, 381-402. https://doi.org/10.3197/096327194776679665

Almansa, C., Calatrava, J., Martínez-Paz, J.M., 2012. Extending the framework of the economic evaluation of erosion control actions in Mediterranean basins. Land Use Policy 29, 294 308. https://doi.org/10.1016/j.landusepol.2011.06.013

Arrow, K.J., Cropper, M.L., Gollier, C., Groom, B., Heal, G.M., Newell, R.G., Nordhaus, W.D., Pindyck, R.S., Pizer, W.A., Portney, P.R., Sterner, T., Tol, R.S.J., Weitzman, M.L., 2014. 
700

701

702

703

704

705

706

707

708

709

710

711

712

713

714

715

716

717

718

719

720

721

722

723

724

725

726

727

728

729

730

731

732

733

734

735

736

737

738

739

Should governments use a declining discount rate in project analysis? Rev. Environ. Econ. Policy 8, 145-163. https://doi.org/10.1093/reep/reu008

Artmann, M., 2015. Managing urban soil sealing in Munich and Leipzig (Germany) - from a wicked problem to clumsy solutions. Land Use Policy 46, 21-37. https://doi.org/10.1016/j.landusepol.2015.02.004

Bartkowski, B., 2017. Are diverse ecosystems more valuable? Economic value of biodiversity as result of uncertainty and spatial interactions in ecosystem service provision. Ecosyst. Serv. 24, 50-57. https://doi.org/10.1016/j.ecoser.2017.02.023

Bartkowski, B., Hansjürgens, B., Möckel, S., Bartke, S., 2018. Institutional Economics of Agricultural Soil Ecosystem Services. Sustainability 10, 2447. https://doi.org/10.3390/su10072447

Bashagaluke, J.B., Logah, V., Opoku, A., Sarkodie-Addo, J., Quansah, C., 2018. Soil nutrient loss through erosion: Impact of different cropping systems and soil amendments in Ghana. PLOS ONE 13, e0208250. https://doi.org/10.1371/journal.pone.0208250

Bastian, O., Syrbe, R.-U., Rosenberg, M., Rahe, D., Grunewald, K., 2013. The five pillar EPPS framework for quantifying, mapping and managing ecosystem services. Ecosyst. Serv. 4, 15-24. https://doi.org/10.1016/j.ecoser.2013.04.003

Baveye, P.C., Baveye, J., Gowdy, J., 2016. Soil “ecosystem” services and natural capital: Critical appraisal of research on uncertain ground. Front. Environ. Sci. 4. https://doi.org/10.3389/fenvs.2016.00041

Bishop, R.C., Boyle, K.J., 2019. Reliability and Validity in Nonmarket Valuation. Environ. Resour. Econ. 72, 559-582. https://doi.org/10.1007/s10640-017-0215-7

Bockstael, N.E., Freeman, A.M., Kopp, R.J., Portney, P.R., Smith, V.K., 2000. On measuring economic values for nature. Environ. Sci. Technol. 34, 1384-1389. https://doi.org/10.1021/es9906731

Bond, C.A., Hoag, D.L., Kipperberg, G., 2011. Agricultural Producers and the Environment: A Stated Preference Analysis of Colorado Corn Producers. Can. J. Agric. Econ. 59, 127144. https://doi.org/10.1111/j.1744-7976.2010.01192.x

Boyd, J., Banzhaf, S., 2007. What are ecosystem services? The need for standardized environmental accounting units. Ecol. Econ. 63, 616-626.

https://doi.org/10.1016/j.ecolecon.2007.01.002

Braat, L.C., 2013. The Value of the Ecosystem Services Concept in Economic and Biodiversity Policy. In: Jacobs, S., Dendoncker, N., Keune, H. (Eds.), Ecosystem Services. Amsterdam, Elsevier, 97-103. https://doi.org/10.1016/B978-0-12-419964-4.00010-X

Brevik, E.C., Pereg, L., Pereira, P., Steffan, J.J., Burgess, L.C., Gedeon, C.I., 2019. Shelter, clothing, and fuel: Often overlooked links between soils, ecosystem services, and human health. Sci. Total Environ. 651, 134-142. https://doi.org/10.1016/j.scitotenv.2018.09.158

Bromley, D.W., 1996. The social construction of land. In: Hagedorn, K. (Ed.), Institutioneller Wandel und Politische Ökonomie von Landwirtschaft und Agrarpolitik. Festschrift zum 65. Geburtstag von Günther Schmitt. Frankfurt: Campus, 21-45. 
740

741

742

743

744

745

746

747

748

749

750

751

752

753

754

755

756

757

758

759

760

761

762

763

764

765

766

767

768

769

770

771

772

773

774

775

776

777

778

779

Budziński, W., Campbell, D., Czajkowski, M., Demšar, U., Hanley, N., 2018. Using Geographically Weighted Choice Models to Account for the Spatial Heterogeneity of Preferences. J. Agric. Econ. 69, 606-626. https://doi.org/10.1111/1477-9552.12260

Burton, R.J.F., Schwarz, G., 2013. Result-oriented agri-environmental schemes in Europe and their potential for promoting behavioural change. Land Use Policy 30, 628-641. https://doi.org/10.1016/j.landusepol.2012.05.002

Campbell, B., Sayer, J.A., Frost, P., Vermeulen, S., Ruiz Pérez, M., Cunningham, A., Prabhu, R., 2001. Assessing the performance of natural resource systems. Conserv. Ecol. 5(2), 22. www.consecol.org/vol5/iss $2 / \operatorname{art} 22 /$

Campbell, E.T., 2018. Revealed social preference for ecosystem services using the eco-price. Ecosyst. Serv. 30, 267-275. https://doi.org/10.1016/j.ecoser.2017.04.009

Cash, D.W., Adger, W.N., Berkes, F., Garden, P., Lebel, L., Olsson, P., Pritchard, L., Young, O., 2006. Scale and cross-scale dynamics: governance and information in a multilevel world. Ecol. Soc. 11(2), 8. www.ecologyandsociety.org/vol11/iss2/art8/

Cavender-Bares, J., Polasky, S., King, E., Balvanera, P., 2015. A sustainability framework for assessing trade-offs in ecosystem services. Ecol. Soc. 20(1), 17. https://doi.org/10.5751/ES-06917-200117

Cerda, C., Fuentes, J.P., Maza, C.L.D.L., Louit, C., Araos, A., 2018. Assessing visitors' preferences for ecosystem features in a desert biodiversity hotspot. Environ. Conserv. 45, 75-82. https://doi.org/10.1017/S0376892917000200

Chan, K.M.A., Guerry, A.D., Balvanera, P., Klain, S., Satterfield, T., Basurto, X., Bostrom, A., Chuenpagdee, R., Gould, R., Halpern, B.S., Hannahs, N., Levine, J., Norton, B., Ruckelshaus, M., Russell, R., Tam, J., Woodside, U., 2012. Where are cultural and social in ecosystem services? A framework for constructive engagement. BioScience 62, 744756. https://doi.org/10.1525/bio.2012.62.8.7

ChoCho, S., Rapera, C.L., 2010. The on-site cost of soil erosion by the replacement cost methods in Inle Lake Watershed, Nyaung Shwe Township, Myanmar. J. Environ. Sci. Manag. 13, 67-81.

Christie, M., Fazey, I., Cooper, R., Hyde, T., Kenter, J.O., 2012. An evaluation of monetary and non-monetary techniques for assessing the importance of biodiversity and ecosystem services to people in countries with developing economies. Ecol. Econ. 83, 67-78. https://doi.org/10.1016/j.ecolecon.2012.08.012

Colombo, S., Calatrava-Requena, J., Hanley, N., 2003. The economic benefits of soil erosion control: An application of the contingent valuation method in the Alto Genil basin of southern Spain. J. Soil Water Conserv. 58, 367-371.

Colombo, S., Calatrava-Requena, J., Hanley, N., 2006. Analysing the social benefits of soil conservation measures using stated preference methods. Ecol. Econ. 58, 850-861. https://doi.org/10.1016/j.ecolecon.2005.09.010

Cord, A.F., Bartkowski, B., Beckmann, M., Dittrich, A., Hermans-Neumann, K., Kaim, A., Lienhoop, N., Locher-Krause, K., Priess, J., Schröter-Schlaack, C., Schwarz, N., Seppelt, 
780

781

782

783

784

785

786

787

788

789

790

791

792

793

794

795

796

797

798

799

800

801

802

803

804

805

806

807

808

809

810

811

812

813

814

815

816

817

818

R., Strauch, M., Václavík, T., Volk, M., 2017. Towards systematic analyses of ecosystem service trade-offs and synergies: Main concepts, methods and the road ahead. Ecosyst. Serv. 28, Part C, 264-272. https://doi.org/10.1016/j.ecoser.2017.07.012

Costanza, R., de Groot, R., Sutton, P., van der Ploeg, S., Anderson, S.J., Kubiszewski, I., Farber, S., Turner, R.K., 2014. Changes in the global value of ecosystem services. Glob. Environ. Change 26, 152-158. https://doi.org/10.1016/j.gloenvcha.2014.04.002

Csárdi, G., 2019. igraph: Network Analysis and Visualization. R package version 1.2.4.1. https://CRAN.R-project.org/package=dplyr

Czajkowski, M., Hanley, N., LaRiviere, J., 2016. Controlling for the effects of information in a public goods discrete choice model. Environ. Resour. Econ. 63, 523-544. https://doi.org/10.1007/s10640-014-9847-z

Daedlow, K., Lemke, N., Helming, K., 2018. Arable Land Tenancy and Soil Quality in Germany: Contesting Theory with Empirics. Sustainability 10, 2880. https://doi.org/10.3390/su10082880

Decaëns, T., Jiménez, J.J., Gioia, C., Measey, G.J., Lavelle, P., 2006. The values of soil animals for conservation biology. Eur. J. Soil Biol., ICSZ 42, S23-S38. https://doi.org/10.1016/j.ejsobi.2006.07.001

Dechen, S.C.F., Telles, T.S., Guimarães, M. de F., De Maria, I.C., 2015. Losses and costs associated with water erosion according to soil cover rate. Bragantia 74, 224-233. https://doi.org/10.1590/1678-4499.0363

de Groot, R.S., Alkemade, R., Braat, L., Hein, L., Willemen, L., 2010. Challenges in integrating the concept of ecosystem services and values in landscape planning, management and decision making. Ecol. Complex. 7, 260-272. https://doi.org/10.1016/j.ecocom.2009.10.006

Derissen, S., Quaas, M.F., 2013. Combining performance-based and action-based payments to provide environmental goods under uncertainty. Ecol. Econ., New Climate Economics 85, 77-84. https://doi.org/10.1016/j.ecolecon.2012.11.001

Díaz, S., Pascual, U., Stenseke, M., Martín-López, B., Watson, R.T., Molnár, Z., Hill, R., Chan, K.M.A., Baste, I.A., Brauman, K.A., Polasky, S., Church, A., Lonsdale, M., Larigauderie, A., Leadley, P.W., van Oudenhoven, A.P.E., van der Plaat, F., Schröter, M., Lavorel, S., Aumeeruddy-Thomas, Y., Bukvareva, E., Davies, K., Demissew, S., Erpul, G., Failler, P., Guerra, C.A., Hewitt, C.L., Keune, H., Lindley, S., Shirayama, Y., 2018. Assessing nature's contributions to people. Science 359, 270-272. https://doi.org/10.1126/science.aap8826

Dominati, E.J., Patterson, M., Mackay, A., 2010. A framework for classifying and quantifying the natural capital and ecosystem services of soils. Ecol. Econ. 69, 1858-1868. https://doi.org/10.1016/j.ecolecon.2010.05.002

Dominati, E.J., Mackay, A., Green, S., Patterson, M., 2014a. A soil change-based methodology for the quantification and valuation of ecosystem services from agro-ecosystems: A case

Peer] reviewing PDF | (2019:10:42110:2:0:NEW 4 Feb 2020) 
819

820

821

822

823

824

825

826

827

828

829

830

831

832

833

834

835

836

837

838

839

840

841

842

843

844

845

846

847

848

849

850

851

852

853

854

855

856

857

858

study of pastoral agriculture in New Zealand. Ecol. Econ. 100, 119-129.

https://doi.org/10.1016/j.ecolecon.2014.02.008

Dominati, E.J., Mackay, A., Lynch, B., Heath, N., Millner, I., 2014b. An ecosystem services approach to the quantification of shallow mass movement erosion and the value of soil conservation practices. Ecosyst. Serv. 9, 204-215. https://doi.org/10.1016/j.ecoser.2014.06.006

Dominati, E.J., Mackay, A.D., Bouma, J., Green, S., 2016. An ecosystems approach to quantify soil performance for multiple outcomes: The future of land evaluation? Soil Sci. Soc. Am. J. 80, 438. https://doi.org/10.2136/sssaj2015.07.0266

Droste, N., Meya, J.N., 2017. Ecosystem services in infrastructure planning - a case study of the projected deepening of the Lower Weser river in Germany. J. Environ. Plan. Manag. 60, 231-248. https://doi.org/10.1080/09640568.2016.1151405

Eastwood, C., Krausse, M., Alexander, R.R., 2000. Muddied Waters: Estimating the national economic cost of soil erosion and sedimentation in New Zealand (No. 123632), 2000 Conference (44th), January 23-25, 2000, Sydney, Australia. Australian Agricultural and Resource Economics Society.

Faccioli, M., Kuhfuss, L., Czajkowski, M., 2019. Stated Preferences for Conservation Policies Under Uncertainty: Insights on the Effect of Individuals' Risk Attitudes in the Environmental Domain. Environ. Resour. Econ. 73, 627-659. https://doi.org/10.1007/s10640-018-0276-2

Fan, F., Henriksen, C.B., Porter, J., 2016. Valuation of ecosystem services in organic cereal crop production systems with different management practices in relation to organic matter input. Ecosyst. Serv. 22, 117-127. https://doi.org/10.1016/j.ecoser.2016.10.007

Förster, J., Schmidt, S., Bartkowski, B., Lienhoop, N., Wittmer, H., Albert, C., 2019. Incorporating environmental costs of ecosystem service loss in political decision making: a synthesis of monetary values for Germany. PLOS One 14(2), e0211419. https://doi.org/10.1371/journal.pone.0211419

Frelih-Larsen, A., Hinzmann, M., Ittner, S., 2018. The 'Invisible' Subsoil: An Exploratory View of Societal Acceptance of Subsoil Management in Germany. Sustainability 10, 3006. https://doi.org/10.3390/su10093006

Ganguly, D., Singh, G., Purvaja, R., Bhatta, R., Paneer Selvam, A., Banerjee, K., Ramesh, R., 2018. Valuing the carbon sequestration regulation service by seagrass ecosystems of Palk Bay and Chilika, India. Ocean Coast. Manag., Seagrass Ecosystems of India 159, 26-33. https://doi.org/10.1016/j.ocecoaman.2017.11.009

Glæsner, N., Helming, K., de Vries, W., 2014. Do Current European Policies Prevent Soil Threats and Support Soil Functions? Sustainability 6, 9538-9563. https://doi.org/10.3390/su6129538

Glenk, K., Colombo, S., 2011. Designing policies to mitigate the agricultural contribution to climate change: an assessment of soil based carbon sequestration and its ancillary effects. Clim. Change 105, 43-66. https://doi.org/10.1007/s10584-010-9885-7

Peer] reviewing PDF | (2019:10:42110:2:0:NEW 4 Feb 2020) 
859 Glenk, K., Johnston, R.J., Meyerhoff, J., Sagebiel, J., 2019. Spatial Dimensions of Stated

860

861

862

863

864

865

866

867

868

869

870

871

872

873

874

875

876

877

878

879

880

881

882

883

884

885

886

887

888

889

890

891

892

893

894

895

896 Preference Valuation in Environmental and Resource Economics: Methods, Trends and Challenges. Environ. Resour. Econ. https://doi.org/10.1007/s10640-018-00311-w

Göpel, M., 2016. The Great Mindshift: How a New Economic Paradigm and Sustainability Transformations Go Hand in Hand. Springer. https://link.springer.com/content/pdf/10.1007\%2F978-3-319-43766-8.pdf

Gutzler, C., Helming, K., Balla, D., Dannowski, R., Deumlich, D., Glemnitz, M., Knierim, A., Mirschel, W., Nendel, C., Paul, C., Sieber, S., Stachow, U., Starick, A., Wieland, R., Wurbs, A., Zander, P., 2015. Agricultural land use changes - a scenario-based sustainability impact assessment for Brandenburg, Germany. Ecol. Indic. 48, 505-517. https://doi.org/10.1016/j.ecolind.2014.09.004

Haines-Young, R., Potschin, M.B., 2018. Common International Classification of Ecosystem Services (CICES) V5.1 and guidance on the application of the revised structure. Available from www.cices.eu.

Hansen, L., Hellerstein, D., 2007. The Value of the Reservoir Services Gained with Soil Conservation. Land Econ. 83, 285-301. https://doi.org/10.3368/le.83.3.285

Hasund, K.P., Johansson, M., 2016. Paying for Environmental Results is WTO Compliant. EuroChoices 15, 33-38. https://doi.org/10.1111/1746-692X.12110

Hattam, C., Böhnke-Henrichs, A., Börger, T., Burdon, D., Hadjimichael, M., Delaney, A., Atkins, J.P., Garrard, S., Austen, M.C., 2015. Integrating methods for ecosystem service assessment and valuation: Mixed methods or mixed messages? Ecol. Econ. 120, 126138. https://doi.org/10.1016/j.ecolecon.2015.10.011

Hausman, J., 2012. Contingent Valuation: From Dubious to Hopeless. J. Econ. Perspect. 26, $43-$ 56. https://doi.org/10.1257/jep.26.4.43

Helgeson, C., Bradley, R., Hill, B., 2018. Combining probability with qualitative degree-ofcertainty metrics in assessment. Clim. Change 149, 517-525. https://doi.org/10.1007/s10584-018-2247-6

Helming, K., Daedlow, K., Paul, C., Techen, A.-K., Bartke, S., Bartkowski, B., Kaiser, D., Wollschläger, U., Vogel, H.-J., 2018. Managing soil functions for a sustainable bioeconomy-Assessment framework and state of the art. Land Degrad. Dev. 29, 31123126. https://doi.org/10.1002/ldr.3066

Hintermann, B., Peterson, S., Rickels, W., 2016. Price and Market Behavior in Phase II of the EU ETS: A Review of the Literature. Rev. Environ. Econ. Policy 10, 108-128. https://doi.org/10.1093/reep/rev015

Hopkins, K.G., Noe, G.B., Franco, F., Pindilli, E.J., Gordon, S., Metes, M.J., Claggett, P.R., Gellis, A.C., Hupp, C.R., Hogan, D.M., 2018. A method to quantify and value floodplain sediment and nutrient retention ecosystem services. J. Environ. Manage. 220, 65-76. https://doi.org/10.1016/j.jenvman.2018.05.013 
897 Hubacek, K., van den Bergh, J.C.J.M., 2006. Changing concepts of 'land' in economic theory:

898

899

900

901

902

903

904

905

906

907

908

909

910

911

912

913

914

915

916

917

918

919

920

921

922

923

924

925

926

927

928

929

930

931

932

933

934

935

936

From single to multi-disciplinary approaches. Ecol. Econ. 56(1), 5-27.

\section{https://doi:10.1016/j.ecolecon.2005.03.033}

Hungate, B.A., Barbier, E.B., Ando, A.W., Marks, S.P., Reich, P.B., van Gestel, N., Tilman, D., Knops, J.M.H., Hooper, D.U., Butterfield, B.J., Cardinale, B.J., 2017. The economic value of grassland species for carbon storage. Sci. Adv. 3, e1601880. https://doi.org/10.1126/sciadv.1601880

Jerath, M., Bhat, M., Rivera-Monroy, V.H., Castañeda-Moya, E., Simard, M., Twilley, R.R., 2016. The role of economic, policy, and ecological factors in estimating the value of carbon stocks in Everglades mangrove forests, South Florida, USA. Environ. Sci. Policy 66, 160-169. https://doi.org/10.1016/j.envsci.2016.09.005

Johnston, R.J., Boyle, K.J., Adamowicz, W. (Vic), Bennett, J., Brouwer, R., Cameron, T.A., Hanemann, W.M., Hanley, N., Ryan, M., Scarpa, R., Tourangeau, R., Vossler, C.A., 2017. Contemporary Guidance for Stated Preference Studies. J. Assoc. Environ. Resour. Econ. 4, 319-405. https://doi.org/10.1086/691697

Jónsson, J.Ö.G., Davíðsdóttir, B., 2016. Classification and valuation of soil ecosystem services. Agric. Syst. 145, 24-38. https://doi.org/10.1016/j.agsy.2016.02.010

Juerges, N., Hagemann, N., Bartke, S., 2018. A tool for analysing instruments for soil governance: The REEL-Framework. J. Environ. Pol. Plann. 20(5), 617-631. https://doi.org/10.1080/1523908X.2018.1474731

Kay, S., Graves, A., Palma, J.H.N., Moreno, G., Roces-Díaz, J.V., Aviron, S., Chouvardas, D., Crous-Duran, J., Ferreiro-Domínguez, N., García de Jalón, S., Măcicăşan, V., MosqueraLosada, M.R., Pantera, A., Santiago-Freijanes, J.J., Szerencsits, E., Torralba, M., Burgess, P.J., Herzog, F., 2019. Agroforestry is paying off - Economic evaluation of ecosystem services in European landscapes with and without agroforestry systems. Ecosyst. Serv. 36, 100896. https://doi.org/10.1016/j.ecoser.2019.100896

Kibria, A.S.M.G., Behie, A., Costanza, R., Groves, C., Farrell, T., 2017. The value of ecosystem services obtained from the protected forest of Cambodia: The case of Veun Sai-Siem Pang National Park. Ecosyst. Serv. 26, 27-36. https://doi.org/10.1016/j.ecoser.2017.05.008

Kiran, G.S., Malhi, R.K.M., 2011. Economic valuation of forest soils. Curr. Sci. 100, 396-399.

Krutilla, J.V., 1967. Conservation reconsidered. Am. Econ. Rev. 57, 777-786.

Kulmatiski, A., Anderson-Smith, A., Beard, K.H., Doucette-Riise, S., Mazzacavallo, M., Nolan, N.E., Ramirez, R.A., Stevens, J.R., 2014. Most soil trophic guilds increase plant growth: a meta-analytical review. Oikos 123, 1409-1419. https://doi.org/10.1111/oik.01767

Kumar, P. (Ed.), 2010. The Economics of Ecosystems and Biodiversity: Ecological and Economic Foundations. Routledge: London, New York.

Laurans, Y., Rankovic, A., Billé, R., Pirard, R., Mermet, L., 2013. Use of ecosystem services economic valuation for decision making: Questioning a literature blindspot. J. Environ. Manage. 119, 208-219. https://doi.org/10.1016/j.jenvman.2013.01.008

Peer] reviewing PDF | (2019:10:42110:2:0:NEW 4 Feb 2020) 
937 Lee, J., Lim, C.-H., Kim, G.S., Markandya, A., Chowdhury, S., Kim, S.J., Lee, W.-K., Son, Y.,

938

939

940

941

942

943

944

945

946

947

948

949

950

951

952

953

954

955

956

957

958

959

960

961

962

963

964

965

966

967

968

969

970

971

972

973

974

975

976 2018. Economic viability of the national-scale forestation program: The case of success in the Republic of Korea. Ecosyst. Serv. 29, 40-46. https://doi.org/10.1016/j.ecoser.2017.11.001

Leonhardt, H., Penker, M., Salhofer, K., 2019. Do farmers care about rented land? A multimethod study on land tenure and soil conservation. Land Use Policy 82, 228-239. https://doi.org/10.1016/j.landusepol.2018.12.006

Leventon, J., Schaal, T., Velten, S., Loos, J., Fischer, J., Newig, J., 2019. Landscape-scale biodiversity governance: Scenarios for reshaping spaces of governance. Environ. Policy Gov. 29(3), 170-184. https://doi.org/10.1002/eet.1845

Levykin, S.V., Chibilev, A.A., Kazachkov, G.V., Petrishchev, V.P., 2017. Application of the soil-ecological multiplicative index to assess suitability of Cis-Ural chernozems for cultivation with due account for economic parameters. Eurasian Soil Sci. 50, 246-252. https://doi.org/10.1134/S1064229317020107

Lienhoop, N., Bartkowski, B., Hansjürgens, B., 2015. Informing biodiversity policy: The role of economic valuation, deliberative institutions and deliberative monetary valuation. Environ. Sci. Policy 54, 522-532. https://doi.org/10.1016/j.envsci.2015.01.007

Liu, X., Jiang, M., Dong, G., Zhang, Z., Wang, X., 2017. Ecosystem Service Comparison before and after Marshland Conversion to Paddy Field in the Sanjiang Plain, Northeast China. Wetlands 37, 593-600. https://doi.org/10.1007/s13157-017-0894-4

Lu, C., Yu, G., Xiao, Y., Xie, G., 2013. Wind tunnel simulation and evaluation of soil conservation function of alpine grassland in Qinghai-Tibet Plateau. Ecol. Econ. 86, 1620. https://doi.org/10.1016/j.ecolecon.2012.10.015

Martín-López, B., Montes, C., Benayas, J., 2007. The non-economic motives behind the willingness to pay for biodiversity conservation. Biol. Conserv. 139, 67-82. https://doi.org/10.1016/j.biocon.2007.06.005

Mastrorilli, M., Rana, G., Verdiani, G., Tedeschi, G., Fumai, A., Russo, G., 2018. Economic Evaluation of Hydrological Ecosystem Services in Mediterranean River Basins Applied to a Case Study in Southern Italy. Water 10, 241. https://doi.org/10.3390/w10030241

Mekuria, W., Veldkamp, E., Tilahun, M., Olschewski, R., 2011. Economic valuation of land restoration: The case of exclosures established on communal grazing lands in Tigray, Ethiopia. Land Degrad. Dev. 22, 334-344. https://doi.org/10.1002/ldr.1001

Miranowski, J.A., Hammes, B.D., 1984. Implicit Prices of Soil Characteristics for Farmland in Iowa. Am. J. Agric. Econ. 66, 745-749. https://doi.org/10.2307/1240990

Montgomery, D.R., 2007. Soil erosion and agricultural sustainability. Proceedings of the National Academy of Sciences 104, 13268-13272.

Moore, W.B., McCarl, B.A., 1987. Off-Site Costs Of Soil Erosion: A Case Study in the Willamette Valley. West. J. Agric. Econ. 12(1), 42-49.

Nathanail, C.P., Boekhold, A.E., Grimski, D., Bartke, S., 2018. The Europeans' Strategic Research Agenda for Integrated Spatial Planning, Land Use and Soil Management. Final 
977

978

979

980

981

982

983

984

985

986

987

988

989

990

991

992

993

994

995

996

997

998

999

1000

1001

1002

1003

1004

1005

1006

1007

1008

1009

1010

1011

1012

1013

1014

public version of Deliverable D4.3 of the HORIZON 2020 project INSPIRATION. EC Grant agreement no: 642372, UBA: Dessau-Roßlau, Germany.

Noe, R.R., Nachman, E.R., Heavenrich, H.R., Keeler, B.L., Hernández, D.L., Hill, J.D., 2016. Assessing uncertainty in the profitability of prairie biomass production with ecosystem service compensation. Ecosyst. Serv. 21, 103-108. https://doi.org/10.1016/j.ecoser.2016.05.004

Pascual, U., Muradian, R., Brander, L., Gómez-Baggethun, E., Martín-López, B., Verma, M., 2010. The economics of valuing ecosystem services and biodiversity. In: Kumar, P. (Ed.), The Economics of Ecosystems and Biodiversity: Ecological and Economic Foundations. Routledge: London, New York, 183-256.

Pascual, U., Termansen, M., Hedlund, K., Brussaard, L., Faber, J.H., Foudi, S., Lemanceau, P., Jørgensen, S.L., 2015. On the value of soil biodiversity and ecosystem services. Ecosyst. Serv. 15, 11-18. https://doi.org/10.1016/j.ecoser.2015.06.002

Pascual, U., Balvanera, P., Díaz, S., Pataki, G., Roth, E., Stenseke, M., Watson, R.T., Başak Dessane, E., Islar, M., Kelemen, E., Maris, V., Quaas, M., Subramanian, S.M., Wittmer, H., Adlan, A., Ahn, S., Al-Hafedh, Y.S., Amankwah, E., Asah, S.T., Berry, P., Bilgin, A., Breslow, S.J., Bullock, C., Cáceres, D., Daly-Hassen, H., Figueroa, E., Golden, C.D., Gómez-Baggethun, E., González-Jiménez, D., Houdet, J., Keune, H., Kumar, R., Ma, K., May, P.H., Mead, A., O’Farrell, P., Pandit, R., Pengue, W., Pichis-Madruga, R., Popa, F., Preston, S., Pacheco-Balanza, D., Saarikoski, H., Strassburg, B.B., van den Belt, M., Verma, M., Wickson, F., Yagi, N., 2017. Valuing nature's contributions to people: the IPBES approach. Curr. Opin. Environ. Sustain. 26-27, 7-16. https://doi.org/10.1016/j.cosust.2016.12.006

Pereira, P., Bogunovic, I., Muñoz-Rojas, M., Brevik, E.C., 2018. Soil ecosystem services, sustainability, valuation and management. Curr. Opin. Environ. Sci. Health, Sustainable soil management and land restoration 5, 7-13. https://doi.org/10.1016/j.coesh.2017.12.003

Pimentel, D., Harvey, C., Resosudarmo, P., Sinclair, K., Kurz, D., McNair, M., Crist, S., Shpritz, L., Fitton, L., Saffouri, R., Blair, R., 1995. Environmental and Economic Costs of Soil Erosion and Conservation Benefits. Science 267, 1117-1123. https://doi.org/10.1126/science.267.5201.1117

Pimentel, D., Wilson, C., McCullum, C., Huang, R., Dwen, P., Flack, J., Tran, Q., Saltman, T., Cliff, B., 1997. Economic and Environmental Benefits of Biodiversity. BioScience 47, 747-757. https://doi.org/10.2307/1313097

Plaas, E., Meyer-Wolfarth, F., Banse, M., Bengtsson, J., Bergmann, H., Faber, J., Potthoff, M., Runge, T., Schrader, S., Taylor, A., 2019. Towards valuation of biodiversity in agricultural soils: A case for earthworms. Ecol. Econ. 159, 291-300. https://doi.org/10.1016/j.ecolecon.2019.02.003

Peer] reviewing PDF | (2019:10:42110:2:0:NEW 4 Feb 2020) 
1015 Porter, J., Costanza, R., Sandhu, H., Sigsgaard, L., Wratten, S., 2009. The Value of Producing

1016

1017

1018

1019

1020

1021

1022

1023

1024

1025

1026

1027

1028

1029

1030

1031

1032

1033

1034

1035

1036

1037

1038

1039

1040

1041

1042

1043

1044

1045

1046

1047

1048

1049

1050

1051

1052

1053

1054

Food, Energy, and Ecosystem Services within an Agro-Ecosystem. AMBIO J. Hum.

Environ. 38, 186-193. https://doi.org/10.1579/0044-7447-38.4.186

Pretty, J.N., Brett, C., Gee, D., Hine, R.E., Mason, C.F., Morison, J.I.L., Raven, H., Rayment, M.D., van der Bijl, G., 2000. An assessment of the total external costs of UK agriculture. Agric. Syst. 65, 113-136. https://doi.org/10.1016/S0308-521X(00)00031-7

Rakotonarivo, O.S., Schaafsma, M., Hockley, N., 2016. A systematic review of the reliability and validity of discrete choice experiments in valuing non-market environmental goods. J. Environ. Manage. 183, Part 1, 98-109. https://doi.org/10.1016/j.jenvman.2016.08.032

R Core Team, 2018. R: A language and environment for statistical computing. R Foundation for Statistical Computing, Vienna, Austria.

Riera, P., Signorello, G., Thiene, M., Mahieu, P.-A., Navrud, S., Kaval, P., Rulleau, B., Mavsar, R., Madureira, L., Meyerhoff, J., Elsasser, P., Notaro, S., De Salvo, M., Giergiczny, M., Dragoi, S., 2012. Non-market valuation of forest goods and services: Good practice guidelines. J. For. Econ. 18, 259-270. https://doi.org/10.1016/j.jfe.2012.07.001

Robinson, D.A., Fraser, I., Dominati, E.J., Davíðsdóttir, B., Jónsson, J.O.G., Jones, L., Jones, S.B., Tuller, M., Lebron, I., Bristow, K.L., Souza, D.M., Banwart, S., Clothier, B.E., 2014. On the value of soil resources in the context of natural capital and ecosystem service delivery. Soil Sci. Soc. Am. J. 78, 685. https://doi.org/10.2136/sssaj2014.01.0017

Rodríguez-Entrena, M., Barreiro-Hurlé, J., Gómez-Limón, J.A., Espinosa-Goded, M., CastroRodríguez, J., 2012. Evaluating the demand for carbon sequestration in olive grove soils as a strategy toward mitigating climate change. J. Environ. Manage. 112, 368-376. https://doi.org/10.1016/j.jenvman.2012.08.004

Rusch, A., Chaplin-Kramer, R., Gardiner, M.M., Hawro, V., Holland, J., Landis, D., Thies, C., Tscharntke, T., Weisser, W.W., Winqvist, C., Woltz, M., Bommarco, R., 2016. Agricultural landscape simplification reduces natural pest control: A quantitative synthesis. Agriculture, Ecosystems \& Environment 221, 198-204. https://doi.org/10.1016/j.agee.2016.01.039

Samarasinghe, O., Greenhalgh, S., 2013. Valuing the soil natural capital: a New Zealand case study. Soil Res. 51, 278. https://doi.org/10.1071/SR12246

Samuelson, P.A., 1938. A note on the pure theory of consumer's behaviour. Economica 5, 6171. https://doi.org/10.2307/2548836

Sandhu, H.S., Wratten, S.D., Cullen, R., Case, B., 2008. The future of farming: The value of ecosystem services in conventional and organic arable land. An experimental approach. Ecol. Econ. 64, 835-848. https://doi.org/10.1016/j.ecolecon.2007.05.007

Schjønning, P., van den Akker, J.J.H., Keller, T., Greve, M.H., Lamandé, M., Simojoki, A., Stettler, M., Arvidsson, J., Breuning-Madsen, H., 2015. Driver-Pressure-State-ImpactResponse (DPSIR) Analysis and Risk Assessment for Soil Compaction-A European Perspective. Advances in Agronomy 133, 183-237. https://doi.org/10.1016/bs.agron.2015.06.001

Peer] reviewing PDF | (2019:10:42110:2:0:NEW 4 Feb 2020) 
1055 Schulte, R.P.O., Creamer, R.E., Donnellan, T., Farrelly, N., Fealy, R., O’Donoghue, C.,

1056

1057

1058

1059

1060

1061

1062

1063

1064

1065

1066

1067

1068

1069

1070

1071

1072

1073

1074

1075

1076

1077

1078

1079

1080

1081

1082

1083

1084

1085

1086

1087

1088

1089

1090

1091

1092

1093

1094

O'hUallachain, D., 2014. Functional land management: A framework for managing soilbased ecosystem services for the sustainable intensification of agriculture. Environ. Sci. Policy 38, 45-58. https://doi.org/10.1016/j.envsci.2013.10.002

Schwilch, G., Lemann, T., Berglund, Ö., Camarotto, C., Cerdà, A., Daliakopoulos, I., Kohnová, S., Krzeminska, D., Marañón, T., Rietra, R., Siebielec, G., Thorsson, J., Tibbett, M., Valente, S., van Delden, H., van den Akker, J., Verzandvoort, S., Vrînceanu, N., Zoumides, C., Hessel, R., 2018. Assessing Impacts of Soil Management Measures on Ecosystem Services. Sustainability 10, 4416. https://doi.org/10.3390/su10124416

Sen, A., 1973. Behaviour and the concept of preference. Economica 40, 241. https://doi.org/10.2307/2552796

Soule, M.J., Tegene, A., Wiebe, K.D., 2000. Land Tenure and the Adoption of Conservation Practices. Am. J. Agric. Econ. 82, 993-1005.

Spash, C.L., 2006. Non-economic motivation for contingent values: Rights and attitudinal beliefs in the willingness to pay for environmental improvements. Land Econ. 82, 602-622. https://doi.org/10.3368/le.82.4.602

Stupak, N., Sanders, J., Heinrich, B., 2019. The Role of Farmers' Understanding of Nature in Shaping their Uptake of Nature Protection Measures. Ecol. Econ. 157, 301-311. https://doi.org/10.1016/j.ecolecon.2018.11.022

Techen, A.-K., Helming, K., 2017. Pressures on soil functions from soil management in Germany. A foresight review. Agron. Sustain. Dev. 37, 64. https://doi.org/10.1007/s13593-017-0473-3

Tegtmeier, E.M., Duffy, M.D., 2004. External Costs of Agricultural Production in the United States. Int. J. Agric. Sustain. 2, 1-20. https://doi.org/10.1080/14735903.2004.9684563

Toman, M., 1998. Why not to calculate the value of the world's ecosystem services and natural capital. Ecol. Econ. 25, 57-60. https://doi.org/10.1016/S0921-8009(98)00017-2

Turnpenny, J., Jordan, A.J., Adelle, C., Bartke, S., Bournaris, T., Kautto, P., Kuittinen, H., Larsen, E.G., Mouglogianni, C., Saarela, S.-R., Weiland, S., 2015. The use of policy formulation tools in the venue of policy appraisal: patterns and underlying motivations. In: Jordan, A., Turnpenny, J. (Ed.), The Tools of Policy Formulation: Actors, Capacities, Venues and Effects. Edward Elgar: Cheltenham, Northampton, 184-204. https://doi.org/10.4337/9781783477043.00021

Turpin, N., ten Berge, H., Grignani, C., Guzmán, G., Vanderlinden, K., Steinmann, H.-H., Siebielec, G., Spiegel, A., Perret, E., Ruysschaert, G., Laguna, A., Giráldez, J.V., Werner, M., Raschke, I., Zavattaro, L., Costamagna, C., Schlatter, N., Berthold, H., Sandén, T., Baumgarten, A., 2017. An assessment of policies affecting Sustainable Soil Management in Europe and selected member states. Land Use Policy 66, 241-249. https://doi.org/10.1016/j.landusepol.2017.04.001

United Nations, 2014. Resolution adopted by the General Assembly on 20 December 2013 [on the report of the Second Committee (A/64/444)] - 68/232. World Soil Day and

Peer) reviewing PDF | (2019:10:42110:2:0:NEW 4 Feb 2020) 
1095

1096

1097

1098

1099

1100

1101

1102

1103

1104

1105

1106

1107

1108

1109

1110

1111

1112

1113

1114

1115

1116

1117

1118

1119

1120

1121

1122

International Year of Soils.

http://www.un.org/en/ga/search/view doc.asp?symbol=A/RES/68/232\&Lang=E

van den Bergh, J.C.J.M., Botzen, W.J.W., 2015. Monetary valuation of the social cost of CO2 emissions: A critical survey. Ecol. Econ. 114, 33-46. https://doi.org/10.1016/j.ecolecon.2015.03.015

van der Meulen, S., Maring, L., Bartkowski, B., Hagemann, N., Arrúe, J.L., Playán, E., Castañeda, C., Herrero, J., Plaza, D., Álvaro-Fuentes, J., Faneca Sànchez, M., Lopatka, A., Siebielec, G., Verboven, J., De Cleen, M., Staes, J., Boekhold, S., Goidts, E., Salomez, J., Creamer, R., Alberico, S., Abdul Malak, D., Soraci, M., Munafo, M., Bal, N., Baritz, R., Cousin, I., Hessel, R., Dejonckheere, A., Bartke, S., Salata, S., Marin, A., Verzandvoort, S., Jones, A., Maes, J., Valecillo, S., De Angelis, A., Innamorati, A., Orgiazzi, A., Bertaglia, M., Teller, A., Forlin, V., Masson, J., Delsalle, J., Olazabal, C., Peeters, B., 2018. Mapping and Assessment of Ecosystems and their Services: Soil ecosystems (No. 1.2). DG Environment: Brussels.

Vogel, H.-J., Bartke, S., Daedlow, K., Helming, K., Kögel-Knabner, I., Lang, B., Rabot, E., Russell, D., Stößel, B., Weller, U., Wiesmeier, M., Wollschläger, U., 2018. A systemic approach for modeling soil functions. SOIL 4, 83-92. https://doi.org/10.5194/soil-4-83$\underline{2018}$

Vrebos, D., Bampa, F., Creamer, R.E., Gardi, C., Ghaley, B.B., Jones, A., Rutgers, M., Sandén, T., Staes, J., Meire, P., 2017. The Impact of Policy Instruments on Soil Multifunctionality in the European Union. Sustainability 9, 407. https://doi.org/10.3390/su9030407

Wegrich, K., Jann, W., 2007. Theories of the policy cycle. In: Fischer, F., Miller, G.J., Sydney, M.S., (Eds.), Handbook of public policy analysis. Taylor \& Francis: Boca Raton, 69-88.

Xiao, Y., Xie, G., Lu, C., Ding, X., Lu, Y., 2005. The value of gas exchange as a service by rice paddies in suburban Shanghai, PR China. Agric. Ecosyst. Environ. 109, 273-283. https://doi.org/10.1016/j.agee.2005.03.016 


\section{Table $\mathbf{1}$ (on next page)}

Common ecosystem services (based on CICES 5.1 classes) provided by agricultural soils in high-performance agricultural systems of the temperate zone that are affected by agricultural management.

Short names used in text are bold. Columns "Main spatial scale" and "Main temporal scale" indicate the scale(s) at which each service is mainly provided. 
1 Table 1: Common ecosystem services (based on CICES 5.1 classes) provided by agricultural

2 soils in high-performance agricultural systems of the temperate zone, that are affected by

3 agricultural management. Short names used in text are bold. Columns "Main spatial scale" and

4 "Main temporal scale" indicate the scale(s) at which each service is mainly provided.

\begin{tabular}{|c|c|c|c|}
\hline $\begin{array}{l}\text { CICE } \\
\text { S Code }\end{array}$ & $\begin{array}{l}\text { Provisioning } \\
\text { Services }\end{array}$ & $\begin{array}{l}\text { Main } \\
\text { Spatial Scale }\end{array}$ & $\begin{array}{l}\text { Main } \\
\text { Temporal Scale }\end{array}$ \\
\hline 1.1.1.1 & $\begin{array}{l}\text { Cultivated terrestrial plants (including fungi, algae) } \\
\text { grown for nutritional purposes [Food production] }\end{array}$ & Field & Short-term \\
\hline 1.1.1.2 & $\begin{array}{l}\text { Fibres and other materials from cultivated plants, } \\
\text { fungi, algae and bacteria for direct use or processing } \\
\text { (excluding genetic materials) }\end{array}$ & Field & Short-term \\
\hline 1.1.1.3 & $\begin{array}{l}\text { Cultivated plants (including fungi, algae) grown as a } \\
\text { source of energy }\end{array}$ & Field & Short-term \\
\hline $\begin{array}{l}\text { CICE } \\
\text { S Code }\end{array}$ & $\begin{array}{l}\text { Regulation \& Maintenance } \\
\text { Services }\end{array}$ & $\begin{array}{l}\text { Main } \\
\text { Spatial Scale }\end{array}$ & $\begin{array}{l}\text { Main } \\
\text { Temporal Scale }\end{array}$ \\
\hline 2.1 .1 .1 & $\begin{array}{l}\text { Bio-remediation by microorganisms, algae, plants, } \\
\text { and animals }\end{array}$ & Field - Landscape & $\begin{array}{l}\text { Short- to } \\
\text { Mid-term }\end{array}$ \\
\hline 2.1.1.2 & $\begin{array}{l}\text { Filtration/sequestration/storage/accumulation by } \\
\text { microorganisms, algae, plants, and animals }\end{array}$ & Field - Landscape & $\begin{array}{l}\text { Short- to } \\
\text { Mid-term }\end{array}$ \\
\hline 2.2 .1 .1 & Control of erosion rates & Field - Landscape & $\begin{array}{l}\text { Short- to } \\
\text { Long-term }\end{array}$ \\
\hline 2.2 .1 .3 & $\begin{array}{l}\text { Hydrological cycle and water flow regulation } \\
\text { (Including flood control, and coastal protection) }\end{array}$ & Landscape & $\begin{array}{l}\text { Short- to } \\
\text { Long-term }\end{array}$ \\
\hline 2.2 .2 .1 & Pollination (or 'gamete' dispersal in a marine context) & Landscape & Short-term \\
\hline 2.2 .2 .3 & $\begin{array}{l}\text { Maintaining nursery populations and habitats } \\
\text { (Including gene pool protection) }\end{array}$ & $\begin{array}{l}\text { Landscape- } \\
\text { international }\end{array}$ & Long- term \\
\hline 2.2 .3 .1 & Pest control (including invasive species) & Field - Landscape & Short-term \\
\hline 2.2 .3 .2 & Disease control & Field - Landscape & Short-term \\
\hline 2.2 .4 .2 & $\begin{array}{l}\text { Decomposition and fixing processes and their effect } \\
\text { on soil quality }\end{array}$ & Field & $\begin{array}{l}\text { Mid- to } \\
\text { Long-term }\end{array}$ \\
\hline 2.2 .5 .1 & $\begin{array}{l}\text { Regulation of the chemical condition of freshwaters by } \\
\text { living processes [Regulation of freshwater } \\
\text { chemistry] }\end{array}$ & $\begin{array}{l}\text { Landscape - } \\
\text { International }\end{array}$ & $\begin{array}{l}\text { Mid- to } \\
\text { Long-term }\end{array}$ \\
\hline 2.2 .5 .2 & $\begin{array}{l}\text { Regulation of the chemical condition of salt waters by } \\
\text { living processes [ Regulation of saltwater chemistry] }\end{array}$ & $\begin{array}{l}\text { Landscape - } \\
\text { International }\end{array}$ & $\begin{array}{l}\text { Mid- to } \\
\text { Long-term }\end{array}$ \\
\hline 2.2 .6 .1 & $\begin{array}{l}\text { Regulation of chemical composition of atmosphere and } \\
\text { oceans [Climate regulation] }\end{array}$ & Global & Long- term \\
\hline 2.2 .6 .2 & $\begin{array}{l}\text { Regulation of temperature and humidity, including } \\
\text { ventilation and transpiration [Microclimate } \\
\text { regulation] }\end{array}$ & Landscape & $\begin{array}{l}\text { Mid- to } \\
\text { Long-term }\end{array}$ \\
\hline $\begin{array}{l}\text { CICE } \\
\text { S Code }\end{array}$ & $\begin{array}{l}\text { Cultural } \\
\text { Services }\end{array}$ & $\begin{array}{l}\text { Main } \\
\text { Spatial Scale }\end{array}$ & $\begin{array}{l}\text { Main } \\
\text { Temporal Scale }\end{array}$ \\
\hline
\end{tabular}




\begin{tabular}{|l|l|l|l|}
\hline 3.1.1.1 & $\begin{array}{l}\text { Characteristics of living systems that that enable } \\
\text { activities promoting health, recuperation or enjoyment } \\
\text { through active or immersive interactions }\end{array}$ & Landscape & $\begin{array}{l}\text { Short- to } \\
\text { Mid-term }\end{array}$ \\
\hline 3.1.1.2 & $\begin{array}{l}\text { Characteristics of living systems that enable activities } \\
\text { promoting health, recuperation or enjoyment through } \\
\text { passive or observational interactions }\end{array}$ & $\begin{array}{l}\text { Landscape } \\
\text { terms of culture or heritage }\end{array}$ & $\begin{array}{l}\text { Short- to } \\
\text { Mid-term }\end{array}$ \\
\hline 3.1.2.4 & $\begin{array}{l}\text { Characteristics of living systems that enable aesthetic } \\
\text { experiences }\end{array}$ & Landscape \\
\hline 3.2.2.1 & $\begin{array}{l}\text { Characteristics or features of living systems that have } \\
\text { an existence value }\end{array}$ & $\begin{array}{l}\text { Landscape - } \\
\text { Global }\end{array}$ & $\begin{array}{l}\text { Short- to } \\
\text { Mid-term }\end{array}$ \\
\hline 3.2.2.2 & $\begin{array}{l}\text { Characteristics or features of living systems that have } \\
\text { an option or bequest value }\end{array}$ & $\begin{array}{l}\text { Landscape - } \\
\text { Global }\end{array}$ \\
\hline
\end{tabular}


Table 2 (on next page)

Overview of publications included in the review 
1 Table 2: Overview of publications included in the review

\begin{tabular}{|c|c|c|c|c|}
\hline Code & Study publication & $\begin{array}{l}\text { Year of } \\
\text { valuati } \\
\text { on }\end{array}$ & Study location & $\begin{array}{l}\text { Type of } \\
\text { valuation }\end{array}$ \\
\hline 1 & Miranowski and Hammes (1984) & 1978 & Iowa, US & Marginal \\
\hline 2 & Moore and McCarl (1987) & NA & $\begin{array}{l}\text { Willamette Valley, } \\
\text { Oregon, US }\end{array}$ & Marginal \\
\hline 3 & Pimentel et al. (1995) & NA & global & Total \\
\hline 4 & Pimentel et al. (1997) & NA & US & Total \\
\hline 5 & Pretty et al. (2000) & 1996 & UK & Total \\
\hline 6 & Colombo et al. (2003) & NA & Alto Genil basin, Spain & Marginal \\
\hline 7 & Tegtmeier and Duffy (2004) & 2002 & US & Total \\
\hline 8 & Xiao et al. (2005) & NA & Shanghai, China & Total \\
\hline 9 & Colombo et al. (2006) & NA & Alto Genil basin, Spain & Marginal \\
\hline 10 & Decaëns et al. (2006) & NA & NA & Total \\
\hline 11 & Hansen and Hellerstein (2007) & 1997 & US & Marginal \\
\hline 12 & Sandhu et al. (2008) & NA & $\begin{array}{l}\text { Canterbury, New } \\
\text { Zealand }\end{array}$ & Total \\
\hline 13 & Porter et al. (2009) & NA & Taastrup, Denmark & Total \\
\hline 14 & ChoCho and Rapera (2010) & 2004 & $\begin{array}{l}\text { Inle Lake Watershed, } \\
\text { Myanmar }\end{array}$ & Total \\
\hline 15 & Bond et al. (2011) & NA & $\begin{array}{l}\text { Northeastern Colorado, } \\
\text { US }\end{array}$ & Marginal \\
\hline 16 & Glenk and Colombo (2011) & 2008 & Scotland, UK & Marginal \\
\hline 17 & Kiran and Kaur (2011) & 2009 & $\begin{array}{l}\text { Halol Range, Gujarat, } \\
\text { India }\end{array}$ & $\begin{array}{l}\text { Non- } \\
\text { marginal } \\
\text { change }\end{array}$ \\
\hline 18 & Mekuria et al. (2011) & NA & Tigray, Ethiopia & Total \\
\hline 19 & Almansa et al. (2012) & NA & Aljibe Basin, Spain & Total \\
\hline 20 & Rodríguez-Entrena et al. (2012) & 2011 & Andalusia, Spain & Marginal \\
\hline 21 & Bastian et al. (2013) & NA & Görlitz, Germany & Total \\
\hline 22 & Lu et al. (2013) & NA & $\begin{array}{l}\text { Qinghai-Tibet Plateau, } \\
\text { China }\end{array}$ & Total \\
\hline 23 & $\begin{array}{l}\text { Samarasinghe and Greenhalgh } \\
(2013)\end{array}$ & 2007 & $\begin{array}{l}\text { Manawatu catchment, } \\
\text { New Zealand }\end{array}$ & Marginal \\
\hline 24 & Alam et al. (2014) & NA & NA & Total \\
\hline 25 & Dominati et al. (2014b) & NA & $\begin{array}{l}\text { Hawke's Bay, New } \\
\text { Zealand }\end{array}$ & Total \\
\hline 26 & Dominati et al. (2014a) & NA & Waikato region, New & Total \\
\hline
\end{tabular}




\begin{tabular}{|l|l|l|l|l|}
\hline & & & Zealand & \\
\hline 27 & Dechen et al. (2015) & 1996 & Campinas, Brazil & Total \\
\hline 28 & Fan et al. (2016) & 2015 & Taastrup, Denmark & Total \\
\hline 29 & Jerath et al. (2016) & NA & $\begin{array}{l}\text { Everglades, Florida, } \\
\text { US }\end{array}$ & Total \\
\hline 30 & Noe et al. (2016) & 2010 & Minnesota, US & Total \\
\hline 31 & Hungate et al. (2017) & NA & $\begin{array}{l}\text { Cedar Creek, } \\
\text { Minnesota, US }\end{array}$ & Marginal \\
\hline 32 & Kibria et al. (2017) & NA & $\begin{array}{l}\text { Veun Sai-Siem Pang } \\
\text { National Park, } \\
\text { Cambodia }\end{array}$ & Total \\
\hline 33 & Levykin et al. (2017) & NA & Orenburg, Russia & Total \\
\hline 34 & Liu et al. (2017) & NA & Sanjiang Plain, China & Total \\
\hline 35 & Bashagaluke et al. (2018) & 2017 & $\begin{array}{l}\text { Anwomaso, Kumasi, } \\
\text { Ghana }\end{array}$ & Total \\
\hline 36 & Campbell (2018) & NA & Maryland, US & Total \\
\hline 37 & Cerda et al. (2018) & 2013 & Llanos de Challe, Chile & Marginal \\
\hline 38 & Ganguly et al. (2018) & NA & $\begin{array}{l}\text { Palk Bay and Chilika, } \\
\text { India }\end{array}$ & Total \\
\hline 39 & Hopkins et al. (2018) & NA & $\begin{array}{l}\text { Difficult Run } \\
\text { watershed, Virginia, } \\
\text { US }\end{array}$ & Total \\
\hline 40 & Lee et al. (2018) & Korea & Total \\
\hline 43 & Kastrorilli et al. (2018) & Monis basin, Italy \\
\hline
\end{tabular}




\section{Table 3 (on next page)}

Application of valuation methods for particular soil-based ecosystem services in analyzed studies (study codes see Table 2) 
1 Table 3: Application of valuation methods for particular soil-based ecosystem services in

2 analyzed studies (study codes see Table 2)

\begin{tabular}{|c|c|c|c|c|}
\hline $\begin{array}{l}\text { Ecosystem service (CICES } \\
\text { class)/Method }\end{array}$ & $\begin{array}{l}\text { Market } \\
\text { price }\end{array}$ & Cost-based & $\begin{array}{l}\text { Revealed } \\
\text { preferences }\end{array}$ & $\begin{array}{l}\text { Stated } \\
\text { preferences }\end{array}$ \\
\hline $\begin{array}{l}\text { Food production, materials or } \\
\text { energy }\end{array}$ & $\begin{array}{l}10,12,25, \\
26,33\end{array}$ & & & \\
\hline $\begin{array}{l}\text { Bio-remediation or } \\
\text { filtration/sequestration }\end{array}$ & & 25,26 & & \\
\hline Control of erosion & & $\begin{array}{l}5,14,19,21, \\
22,32,36, \\
40,41\end{array}$ & 1 & $6,15,19,37$ \\
\hline Hydrological cycle & 42 & $\begin{array}{l}2,3,7,11, \\
25,26,28, \\
32,34,41\end{array}$ & 23 & \\
\hline Pest control & & $25,26,43$ & & \\
\hline $\begin{array}{l}\text { Regulation of freshwater } \\
\text { chemistry }\end{array}$ & & $2,7,12,39$ & & 9 \\
\hline Climate regulation & $\begin{array}{l}8,12,13,25 \\
26,42\end{array}$ & $\begin{array}{l}5,8,22,28, \\
29,30,31, \\
32,38\end{array}$ & & 16,20 \\
\hline Decomposition and fixing & 13,24 & $\begin{array}{l}3,4,12,13, \\
14,17,18, \\
22,25,26, \\
27,28,32,35\end{array}$ & & \\
\hline Active interactions & & 7 & & \\
\hline $\begin{array}{l}\text { [non-CICES] Physical } \\
\text { environment }\end{array}$ & 25,26 & 25,26 & & \\
\hline
\end{tabular}


Figure 1

The Total Economic Value framework with insurance value

Source: own elaboration based on Bartkowski (2017)

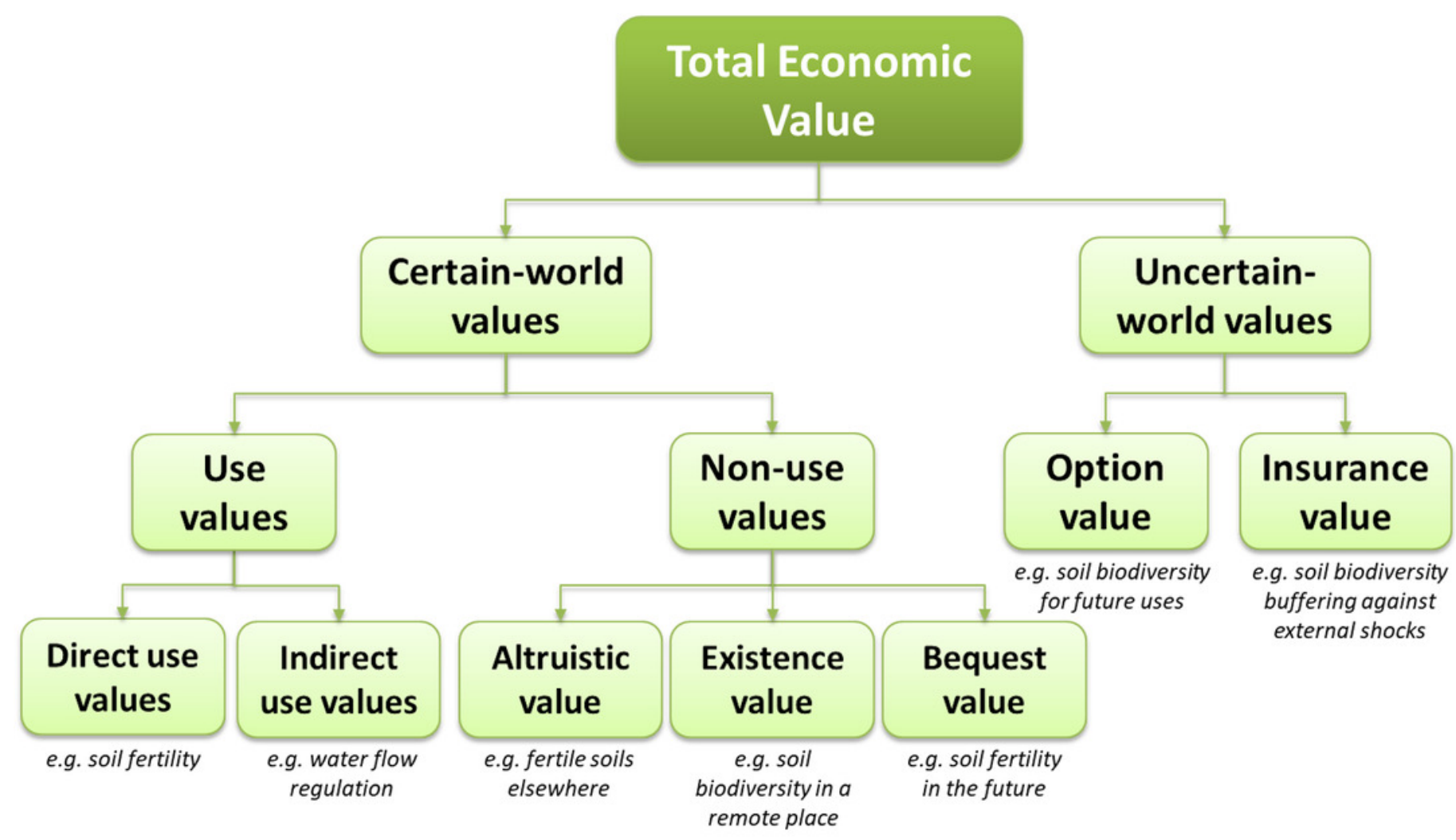


Figure 2

Network graph of ecosystem service co-occurrences across reviewed valuation studies [source: own elaboration].

Note: Vertix sizes indicate number of occurrences of an ecosystem service; edge widths correspond to frequency of co-occurrence.

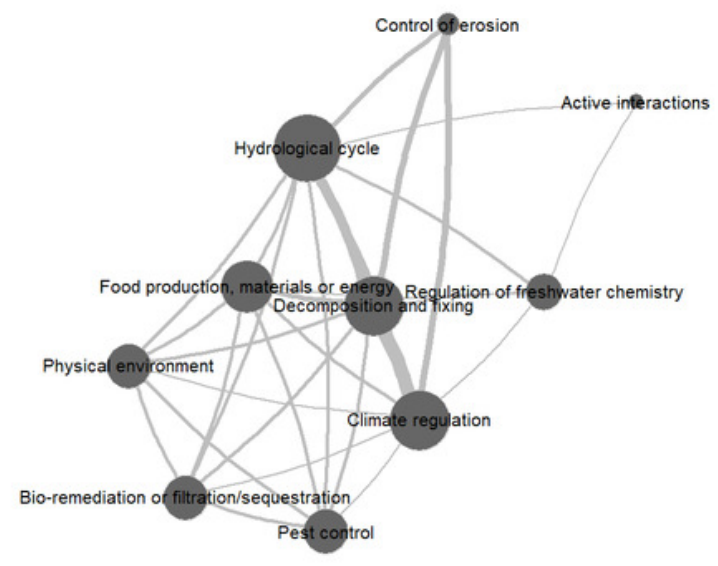

